\title{
Renewable Energy Requirements for Future Building Codes: Options for Compliance
}

HE Dillon

CA Antonopoulos

AE Solana

BJ Russo

September 2011

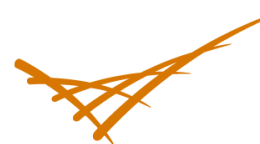

Pacific Northwest

NATIONAL LABORATORY

Proudly Operated by Battelle Since 1965 


\title{
DISCLAIMER
}

This report was prepared as an account of work sponsored by an agency of the United States Government. Neither the United States Government nor any agency thereof, nor Battelle Memorial Institute, nor any of their employees, makes any warranty, express or implied, or assumes any legal liability or responsibility for the accuracy, completeness, or usefulness of any information, apparatus, product, or process disclosed, or represents that its use would not infringe privately owned rights. Reference herein to any specific commercial product, process, or service by trade name, trademark, manufacturer, or otherwise does not necessarily constitute or imply its endorsement, recommendation, or favoring by the United States Government or any agency thereof, or Battelle Memorial Institute. The views and opinions of authors expressed herein do not necessarily state or reflect those of the United States Government or any agency thereof.

\author{
PACIFIC NORTHWEST NATIONAL LABORATORY \\ operated by \\ BATTELLE \\ for the \\ UNITED STATES DEPARTMENT OF ENERGY \\ under Contract DE-AC05-76RL01830
}

\author{
Printed in the United States of America \\ Available to DOE and DOE contractors from the \\ Office of Scientific and Technical Information, \\ P.O. Box 62, Oak Ridge, TN 37831-0062; \\ ph: (865) 576-8401 \\ fax: $(865) 576-5728$ \\ email: reports@adonis.osti.gov
}

Available to the public from the National Technical Information Service

5301 Shawnee Rd., Alexandria, VA 22312

ph: (800) 553-NTIS (6847)

email: orders@ntis.gov <http://www.ntis.gov/about/form.aspx>

Online ordering: http://www.ntis.gov 
PNNL-20727

\title{
Renewable Energy Requirements for Future Building Codes: Options for Compliance
}

\author{
HE Dillon \\ CA Antonopoulos \\ AE Solana \\ BJ Russo
}

September 2011

Prepared for the U.S. Department of Energy under Contract DE-AC05-76RL01830

Pacific Northwest National Laboratory

Richland, Washington 99352 




\section{Summary}

As the model energy codes are improved to reach efficiency levels 50 percent greater than current codes, installation of on-site renewable energy generation is likely to become a code requirement. This requirement will be needed because traditional mechanisms for code improvement, including the building envelope, mechanical systems, and lighting, have been maximized at the most cost-effective limit.

Research has been conducted to determine the mechanism for implementing this requirement (Kaufman 2011). Kaufmann et al. determined that the most appropriate way to structure an on-site renewable requirement for commercial buildings is to define the requirement in terms of an installed power density per unit of roof area. This provides a mechanism that is suitable for the installation of photovoltaic (PV) systems on future buildings to offset electricity and reduce the total building energy load. Kaufmann et al. suggested that an appropriate maximum for the requirement in the commercial sector would be $4 \mathrm{~W} / \mathrm{ft}^{2}$ of roof area or $0.5 \mathrm{~W} / \mathrm{ft}^{2}$ of conditioned floor area.

As with all code requirements, there must be an alternative compliance path for buildings that may not reasonably meet the renewables requirement. This might include conditions like shading (which makes rooftop PV arrays less effective), unusual architecture, undesirable roof pitch, unsuitable building orientation, or other issues. In the short term, alternative compliance paths including high performance mechanical equipment, dramatic envelope changes, or controls changes may be feasible. These options may be less expensive than many renewable systems, which will require careful balance of energy measures when setting the code requirement levels. As the stringency of the code continues to increase however, efficiency trade-offs will be maximized, requiring alternative compliance options to be focused solely on renewable electricity trade-offs or equivalent programs.

One alternate compliance path includes purchase of Renewable Energy Credits (RECs). Each REC represents a specified amount of renewable electricity production and provides an offset of environmental externalities associated with non-renewable electricity production. The purpose of this paper is to explore the possible issues with RECs and comparable alternative compliance options. Existing codes have been examined to determine energy equivalence between the energy generation requirement and the RECs alternative over the life of the building. The price equivalence of the requirement and the alternative are determined to consider the economic drivers for a market decision.

This research includes case studies that review how the few existing codes have incorporated RECs and some of the issues inherent with REC markets. Section 1 of the report reviews compliance options including RECs, green energy purchase programs, shared solar agreements and leases, and other options.

Section 2 provides detailed case studies on codes that include RECs and community based alternative compliance methods. The methods the existing code requirements structure alternative compliance options like RECs are the focus of the case studies.

Section 3 explores the possible structure of the renewable energy generation requirement in the context of energy and price equivalence. The price of RECs have shown high variation by market and over time which makes it critical to for code language to be updated frequently for a renewable energy generation requirement or the requirement will not remain price-equivalent over time.

An analysis technique is proposed to evaluate the incentive for a builder to choose either an on-site PV array or REC purchases. Using this technique the present ASHRAE 189.1 and City of Seattle code requirements were evaluated. 
- For a commercial building with a 70-year life, the ASHRAE 189.1 requirement is not energy- or price-equivalent for the REC alternative compliance path. This may be by design due to the wording of the requirement to restrict the use of RECs to buildings that can prove the renewable energy generation requirement is not reasonable.

- For a commercial building with a 70-year life, the Seattle requirement is more than energyequivalent and price-equivalent for the REC alternative compliance path only in the second year of the code.

- A proposed maximum level REC alternative compliance path based on the Kaufmann et al. findings is evaluated using current market conditions and a price-equivalent REC trade-off is proposed.

- These results indicate that, based on current market conditions, additional incentives are needed to encourage PV installation and to make the REC compliance option appropriate for the building energy codes.

Section 4 of the report provides a maximum case estimate for impact to the PV market and the REC market based on the Kaufmann et al. proposed requirement levels. If all new buildings in the commercial sector complied with the requirement to install rooftop PV arrays, nearly 4,700 MW of solar would be installed in 2012, a major increase from EIA estimates of $640 \mathrm{MW}$ of solar generation capacity installed in 2009. The residential sector could contribute roughly an additional 2,300 MW based on the same code requirement levels of $4 \mathrm{~W} / \mathrm{ft}^{2}$ of roof area.

For the REC market, the largest impact estimate is based on all new construction complying with the code by purchasing RECs instead of installing renewable energy systems like PV (maximum possible result). For an energy equivalent requirement this could result in 72.6-476 million RECs purchased in 2012 depending on the code requirement, while the current RECs markets may be closer to 92 million RECs. If a price equivalent RECs requirement is in place the market impact is larger. The repercussions for the market could be dramatic, and this analysis indicates the need to design the code requirement carefully to incentivize on-site PV systems so the RECs market does not become volatile. RECs would, at the least, become much more expensive which would provide sufficient incentive for on-site renewables. The price increase would provide a greater incentive for development of other new renewables projects, which would in turn generate more RECs.

Section 5 of the report provides a basic framework for draft code language recommendations based on the analysis of the alternative compliance levels. The proposed code language is included.

Several conclusions are possible from this analysis effort:

- Due to the current cost of PV array derived electricity (approximately $0.25 \$ / \mathrm{kWh}$ in this analysis) and the low price of RECs $(\$ 0.02 / \mathrm{kWh})$, a requirement for on-site renewable energy based only on energy equivalence will result in no solar array development. The price incentive will dramatically favor purchase of RECs, and builders will follow the lowest compliance price option.

- To address this issue, the code requirement should be based on price equivalence rather than energy equivalence. An analysis technique for this calculation is proposed to aid future code development work and code adopters.

- The impact to the solar PV array and REC markets from this type of requirement may be substantial. Additional economic research about market impact should be performed once a draft requirement has been established based on an energy equivalence standard. 



\section{Acronyms and Abbreviations}

AEO

AF

ANSI

ASHRAE

CBECS

CORE

DOD

DOE

EIA

EISA

EPAct

ERCOT

FEMP

HVAC

ICC

IECC

IESNA

LBNL

NAECA

NDAA

NREL

NZEB

PNNL

PV

REC

RECS

REMP

RPS

USGBC
Annual Energy Outlook

Air Force

American National Standards Institute

American Society of Heating, Refrigerating and Air-Conditioning Engineers

Commercial Building Energy Consumption Survey

Community Office for Resource Efficiency

Department of Defense

Department of Energy

Energy Information Administration

Energy Independence and Security Act

Energy Policy Act of 2005

Electric Reliability Council of Texas

Federal Energy Management Program

Heating, Ventilation and Air Conditioning

International Code Council

International Energy Conservation Code

Illuminating Engineering Society of North America

Lawrence Berkley National Laboratory

National Appliance Energy Conservation Act

National Defense Authorization Act

National Renewable Energy Laboratory

Net Zero Energy Building

Pacific Northwest National Laboratory

Photovoltaic

Renewable Energy Credit

Residential Energy Consumption Survey

Renewable Energy Mitigation Program

Renewable Portfolio Standard

United States Green Building Council 



\section{Contents}

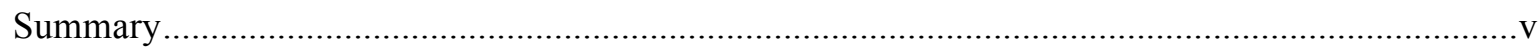

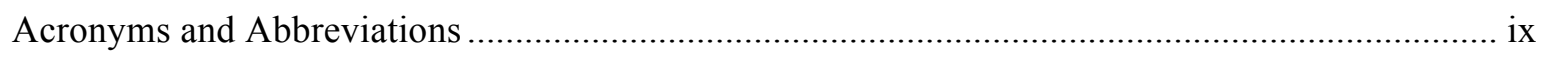

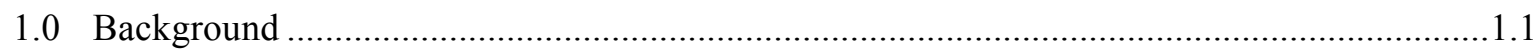

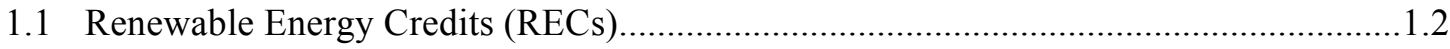

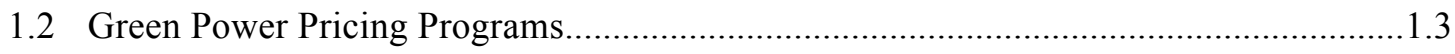

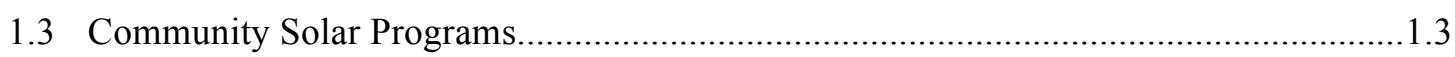

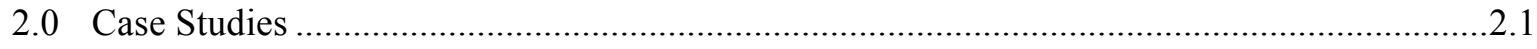

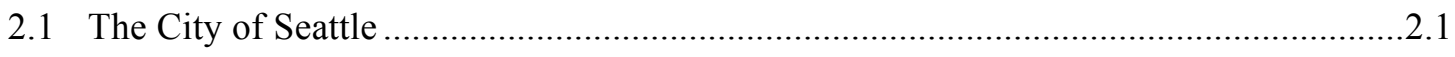

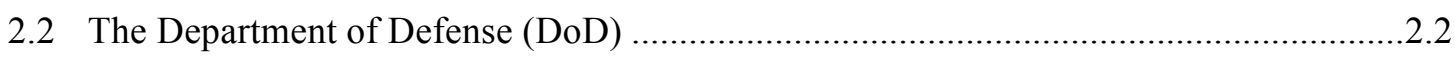

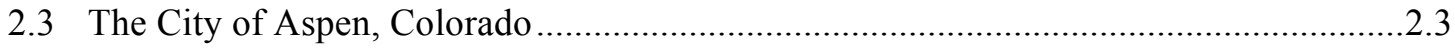

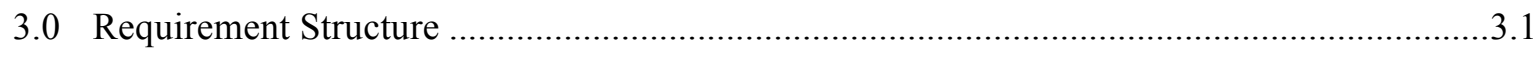

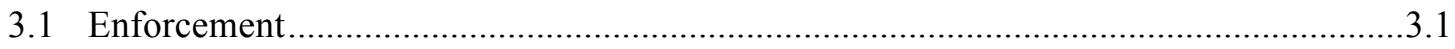

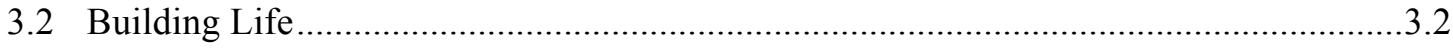

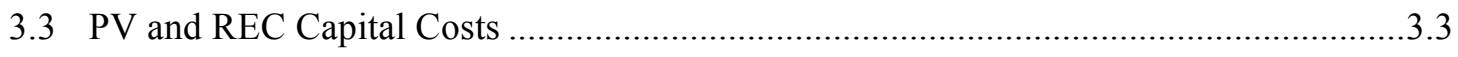

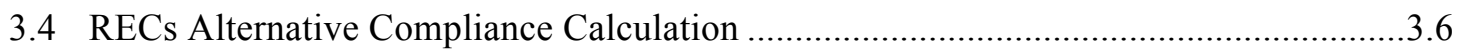

3.5 RECs Alternative Compliance Calculation Based on Present Prices ..............................10

4.0 Estimate of Requirement Impacts ................................................................................. 4.1

4.1 Impact of Commercial Buildings Renewable Requirement .......................................... 4.1

4.2 Impact of Residential Buildings Renewable Requirement ........................................... 4.3

4.3 Impact of Commercial Buildings RECs ................................................................... 4.5

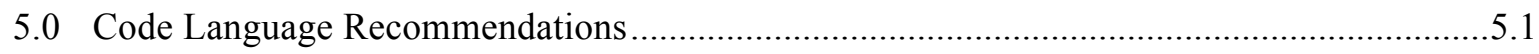

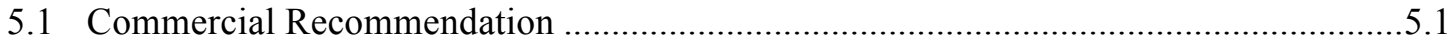

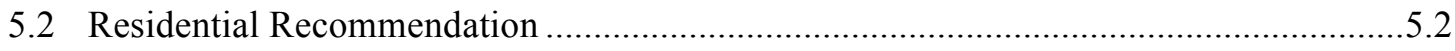

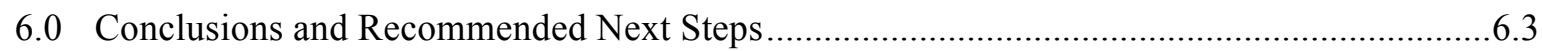

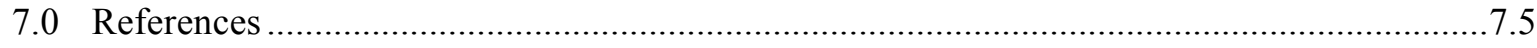

Appendix A - Additional Code Language ................................................................. 7.8 


\section{Figures}

Figure 2. Scenario 1 Price Assumptions. Initially the cost of PV is much more than that of RECs, and then the two prices converge. (This scenario is not intended to represent future price projections).

Figure 3. Scenario 1 Energy Requirements. Initially the RECs alternative compliance option requirement would be much more than the PV requirement in terms of energy, and then the two requirements become closer over time. The large buffer between the two requirements is caused by the non-cost weighting factor, $\mathrm{E}_{\mathrm{w}}$, and the price difference between PV and RECs.3.8

Figure 4. Scenario 2 Price Assumptions. Initially the cost of PV is much more than the price of RECs, and then the two prices converge and then diverge. (This scenario is not intended to represent future price projections).

Figure 5. Scenario 2 Energy Requirements. Initially the REC alternative compliance option requirement is much higher than the PV requirement, and then the two requirements become closer over time and diverge again. The buffer between the two requirements at the closest point is caused by the non-cost weighting factor, $E_{\mathrm{w}}$

Figure 6: Newly Installed MW by Year on Commercial Buildings, Assuming $4 \mathrm{~W} / \mathrm{ft}^{2}$ of Roof

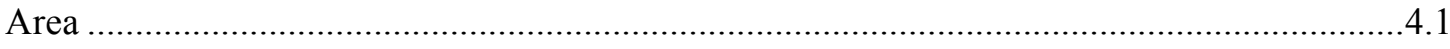

Figure 7: Number of Floors in Commercial Buildings............................................................... 4.2

Figure 8: Newly Installed MW by Year on Residential Buildings, Assuming $4 \mathrm{~W} / \mathrm{ft}^{2}$ of Roof Area

Figure 9: Number of Stories in Residential Buildings. Residential Buildings with more than 4 stories are often considered to be commercial buildings by the model energy codes...............4.4

Figure 10: Potential Future REC Purchases for Commercial Buildings Assuming Price Equivalence

Figure 11. Insolation for Flat-Plate Collectors at Latitude Tilt. In other words, a flat collector (rather than a curved concentrating collector) tilted at each site's latitude (NREL 2011)......6.4 


\section{Tables}

Table 1. Installed PV prices from several literature sources.

Table 2. 2010 REC Prices for Several Voluntary Markets (DOE 2011b). The average price for

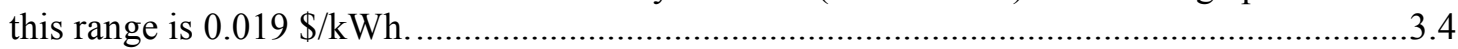

Table 3. Description of Calculation Inputs and a Range of Typical Values ....................................

Table 4. Existing RECs Alternative compliance option Levels for an Example Building of 10,000 $\mathrm{ft}^{2}$ Assuming a Building Lifespan of 70 Years...................................................................... 3.11

Table 5: Summary of worst case impact (100\% compliance via RECs) to the REC markets in 2012 for different code scenarios. For reference, the current REC market is estimated to be 63-157 million MWh (Bird et al. 2010) 



\subsection{Background}

Current model energy codes (IECC and ASHRAE 90.1) do not have prescriptive requirements for onsite renewable energy systems. Recently, ASHRAE Standard 189.1, Standard for the Design of HighPerformance Green Buildings, was developed by the American National Standards Institute (ANSI), American Society of Heating, Refrigerating and Air-Conditioning Engineers (ASHRAE), United States Green Building Council (USGBC) and Illuminating Engineering Society of North America (IESNA). This standard approaches green building in the commercial sector through five key areas of focus: sustainable sites, water use efficiency, energy efficiency, a building's impact on the atmosphere, materials and resources, and indoor environmental quality (ASHRAE 2010). On-site renewable energy systems are included in the provision that addresses energy efficiency. The IGCC (International Green Construction Code) is also developing requirements for onsite renewable energy generation.

The mandatory requirement for on-site renewable energy systems in ASHRAE Standard 189.1 focuses on roof-installed PV systems capable of producing at least $6.0 \mathrm{kBtu} / \mathrm{ft}^{2} /$ year of energy per square foot of conditioned space. This requirement is lowered to $4.0 \mathrm{kBtu} / \mathrm{ft}^{2} /$ year if heating, ventilation and air conditioning (HVAC) systems and appliances have efficiencies exceeding the Energy Policy Act of 2005 (EPAct), National Appliance Energy Conservation Act (NAECA) and Energy Independence and Security Act (EISA) standards. Exceptions to the standard include roof areas with solar radiation levels lower than $4.0 \mathrm{kWh} / \mathrm{m}^{2} /$ day because of geographical location or shading from existing buildings, trees or other objects (ASHRAE 2010). The primary alternative compliance option available for buildings, which cannot comply with the requirement, includes purchase of Green-e certified RECs of at least $7 \mathrm{kWh} / \mathrm{ft}^{2}$ of conditioned space per year until $70 \mathrm{kWh} / \mathrm{ft}^{2}$ has been reached (10 years).

Green-e Energy is a nongovernmental organization that advocates the expansion of renewable electricity generation. The Green-e National Standard (Green-e Energy 2011) certifies the sale of renewable electricity products, including RECs, in an effort to expand renewable energy projects and promote alternative electricity markets.

The code language for the on-site renewable system is shown below from ASHRAE Standard 189.1 (ASHRAE 2010). One concern with the code language is the lack of flexibility for a building that might not be able to comply for other reasons than those listed. This restriction is intended to prevent the purchase of RECs unless the building has a legitimate technical reason to do so, which reduces the market price influence on the requirement.

7.4.1.1 On-Site Renewable Energy Systems. Building projects shall contain on-site renewable energy systems that provide the annual energy production equivalent of not less than $6.0 \mathrm{kBtu} / \mathrm{ft}^{2}\left(20 \mathrm{kWh} / \mathrm{m}^{2}\right)$ of conditioned space. The annual energy production shall be the combined sum of all on-site renewable energy systems.

Exception: Buildings that demonstrate compliance with both of the following are not required to contain on-site renewable energy systems:

1. An annual daily average incident solar radiation available to a flat plate collector oriented due south at an angle from horizontal equal to the latitude of the collector location less than 4.0 $\mathrm{kW} / \mathrm{m}^{2}$-day, accounting for existing buildings, permanent infrastructure that is not part of the building project, topography, and trees, and

2. Purchase of renewable electricity products complying with the Green-e Energy National Standard for Renewable Electricity Products of at least $7 \mathrm{kWh} / \mathrm{ft}^{2}\left(75 \mathrm{kWh} / \mathrm{m}^{2}\right)$ of 
conditioned space each year until the cumulative purchase totals $70 \mathrm{kWh} / \mathrm{ft}^{2}\left(750 \mathrm{kWh} / \mathrm{m}^{2}\right)$ of conditioned space.

Although few agencies/jurisdictions have adopted ASHRAE Standard 189.1, there are efforts under way to promote these green building codes. The city of Seattle, WA, and the U.S. Army have enacted on-site renewable requirements for new and existing buildings and each example is explained in more detail in the case study section of this report.

In addition to ASHRAE Standard 189.1, code changes proposed in the current International Code Council (ICC) development process for the International Green Construction Code (IGCC) would put an on-site renewable energy requirement in place. The first proposed change is to add a prescriptive requirement for on-site renewable systems, which would have the capacity to supply at least two percent of total building energy consumption annually (ICC 2011). Systems promoted by the proposed code include roof-mounted PV panel systems, site-located PV panel systems, building-integrated PV systems and wind energy systems. Proposed IGCC language is presented in Appendix A.

\subsection{Renewable Energy Credits (RECs)}

RECs, also commonly referred to as green tags, are the environmental attributes of electricity produced from renewable energy sources that can be sold separately from the actual electricity. The separation of the energy from its environmental attributes is referred to as unbundling. One REC is equivalent to 1 MWh per the standard market definition.

There are two types of REC markets in the United States: compliance and voluntary. Compliance markets are driven by renewable portfolio standards (RPS) or other state or utility mandates dictating that a portion of delivered energy must come from renewable resources. Voluntary markets allow consumers to buy RECs to support green power whether or not they have access to green power through their local utility. The voluntary market is any purchase of RECs performed in the absence of an RPS or other mandate.

Each compliance market has its own regulations. These may include restrictions on the location (e.g., customer sited systems) and implementation date of the renewable energy project (e.g., on or after January 2005), or there may be specific requirements on how much energy from a particular renewable resource (e.g., $1 \%$ of sold electricity must derive from solar power plants) must be produced (this is often described as a carve-out). There are usually rigorous standards for documentation that assure buyers that the RECs are as represented in terms of quantity, production date, and source. An example of a statewide compliance REC market is found in Texas, where the market is operated by the Electric Reliability Council of Texas (ERCOT). Some states have coordinated their REC requirements and support the operation of a regional REC market. In general, regional REC markets for mandatory programs are limited to areas where adjacent states have similar renewable requirements or wish to share administrative costs. For example, a regional market exists in the Mid-Atlantic States.

Voluntary RECs are purchased primarily for environmental concern or public relations purposes. For instance, by purchasing RECs, a company can advertise that it gets its electricity from renewable sources. Federal agencies purchase RECs from the voluntary market because they are less expensive than those in compliance markets, and therefore are a lower-cost approach to meeting Federal renewable energy mandates. There are several groups that organize voluntary REC markets, and there are numerous REC 
marketers, including project developers. As a result, in the voluntary market it may be more difficult to definitively prevent double counting of voluntary RECs, whereas such double counting is closely monitored and prohibited in compliance markets. There are several third-party certification and verification programs for both voluntary and compliance markets, with Green-e being the leader, and regional tracking systems are emerging as the accounting method of choice, especially for compliance markets.

\subsection{Green Power Pricing Programs}

A green power pricing program is a voluntary program offered by utilities that allows their customers to pay a premium to purchase electricity generated by renewable resources rather than from the utility's regular portfolio. Normally, these programs follow a pricing model in which an additional charge is added to a customer's regular monthly electric bill to support the development of renewable energy projects. Programs usually set a fixed cost, typically $\$ 2$ to $\$ 6$ per $100-\mathrm{kWh}$ block of renewable power.

Opting into a green power pricing program will not replace a customer's existing electricity source or monthly bill. Money paid to a green pricing program is in addition to whatever standard rates the consumer must pay regularly. Participating in the program simply gives a utility the money and authority to deliver more green energy to its grid - energy that is not normally part of its portfolio. The sources of this green energy can be existing projects or the funds can be dedicated to the development of new projects. In the case of new projects, development obviously must lag behind collection of the premium payments and is dependent on resource availability. Although these programs are viable alternatives to onsite renewable systems, they are not available in all parts of the country.

\subsection{Community Solar Programs}

Community solar programs are voluntary initiatives that support development and distribution of solar electricity to a finite number of end users. Community solar programs can be sponsored by utilities, businesses or nonprofit entities; include a third-party installer; and distribute ownership to many community members. Successful programs are supported by policy and standards that allow virtual net metering and group billing for participants. Typically, community solar owners pay some of the up-front equipment costs, and then a specified amount per kWh of electricity produced.

For example, the Clean Energy Collective program in Colorado shares ownership between 18-20 residents. Each participant paid an up-front equipment cost of $\$ 725$ per panel and receives electricity produced from the project at $\$ 0.11$ per kWh (Farrell 2010). All owners are members of Holy Cross Energy, the local energy collective. State and federal incentives were included in the costs. 



\subsection{Case Studies}

This section describes three examples of commercial and residential onsite renewable code developments that have actually implemented requirements for renewable energy generation. These examples represent the best insights about how compliance with RECs has evolved for different requirements. The city of Seattle is highlighted as a commercial example through Director's Rule 2011, which mandates on-site renewable systems. The Department of Defense uses on-site renewable energy systems and RECs to comply with EPAct 2005 and other requirements. Finally, Pitkin County, Colorado, has had a residential code requirement for specific end uses since 2001.

\subsection{The City of Seattle}

The state of Washington has traditionally adopted a state-developed energy code. The current state code is as stringent as the 2009 International Energy Conservation Code (IECC). The City of Seattle has included additional amendments to the state code that address the significant climate difference between the city, which has a marine climate, and the east side of the state which is sunny and drier.

In 2010, Seattle amended the city's 2009 energy code to include an on-site renewable energy system requirement. Chapter 16 of the energy code adds a renewable energy requirement for new buildings and additions of more than 5,000 $\mathrm{ft}^{2}$ through partial adoption of ASHRAE Standard 189.1-2009 (WSL 2011). To meet the renewable energy requirement, building projects will need to add renewable generation systems that provide annual energy production equivalent to $500 \mathrm{Btu} / \mathrm{ft}^{2}\left(0.15 \mathrm{kWh} / \mathrm{ft}^{2}\right)$ of gross conditioned floor area (WSL 2011). Annual renewable energy production will be the sum of all on-site renewable energy systems, including solar thermal systems. The following is the language of the Seattle code:

\section{Chapter 16}

\section{On-Site Renewable Energy Systems}

1601 Scope: This chapter covers the requirements for on-site renewable energy systems. This chapter applies to new buildings and additions more than $5,000 \mathrm{ft}^{2}$ to existing buildings

1610 General Requirements: The building on-site renewable energy system shall comply with one of the following paths:

a. Prescriptive Section 1621

b. Systems Analysis. See section 1141.4

1620 Prescriptive Option for On-Site Renewable Energy Systems.

1621 Annual Production of On-Site Renewable Energy Systems. Building projects shall contain onsite renewable energy systems that provide the annual energy production equivalent of $500 \mathrm{Btu} / \mathrm{ft}^{2}$ of gross conditioned floor area. The annual energy production shall be the combined sum of all on-site renewable energy systems.

EXCEPTION. Purchase of renewable electricity products complying with the Green-e Energy National Standard for Renewable Electricity Products of at least $7 \mathrm{kWh} / \mathrm{ft}^{2}$ of conditioned space each year until the cumulative purchase totals $70 \mathrm{kWh} / \mathrm{ft}^{2}$ of conditioned space (WSL, 2011).

While the Seattle code is modeled closely after ASHRAE Standard 189.1, the electricity production requirements are lower and the REC trade-off is higher. Onsite renewable electricity generation amounts to approximately $1 / 12$ of the ASHRAE standard, but REC purchases are significantly more because they 
are required to be purchased up front as opposed to spread over 10 years. This fact contributes to the energy and price equivalency discussed in Section 3.

Two alternative methods of compliance include increased mechanical system efficiency or purchase of RECs that comply with the Green-e Energy National Standard for Renewable Electricity Products. The two alternate compliance options have been designed for sites or projects in which renewable energy systems are not practical. The first option requires installation of high efficiency space heating and cooling equipment equivalent to 1.10 times the minimum efficiency requirements of the Washington State Energy Code. The second alternative includes purchasing one year of RECs in compliance with the Green-e Energy Standard of at least $70 \mathrm{kWh} / \mathrm{ft}^{2}$ of conditioned space. This amount will increase to 125 $\mathrm{kWh} / \mathrm{ft}^{2}$ after July 1, 2012. RECs are required to be purchased and paid in full before a building permit will be issued.

The Seattle rule is overseen by the Seattle Department of Planning and Development. Chapter 16 of the energy code that establishes an on-site renewable energy requirement was approved by code developers and went into effect on July 14, 2011. At this time, any permit submissions under the new energy code are still under review as implementation is just under way.

\subsection{The Department of Defense (DoD)}

The Federal government provides a second useful case study of renewable energy requirements and the use of RECs as a compliance option. Government agencies are required to have a renewable energy portfolio for compliance with the Energy Policy Act (EPAct) 2005, Section 203, and Executive Order (EO) 13423. Another requirement for the DOD is codified in the National Defense Authorization Act (NDAA). Certain agencies have their own renewable energy goals and mandates. Specifically, DOD's 2008 National Defense Authorization Act established a goal of sourcing 25\% of all energy from renewable resources. These policies are described in Table 1.

Table 1: Legislated Renewable Energy Targets for DoD

\begin{tabular}{|l|c|c|c||}
\hline & $\begin{array}{c}\text { EPAct Section } \\
\mathbf{2 0 3}\end{array}$ & $\begin{array}{c}\text { Executive Order } \\
\mathbf{1 3 4 2 3}\end{array}$ & $\begin{array}{c}\text { National Defense } \\
\text { Authorization Act }\end{array}$ \\
\hline Target / Goal & $\begin{array}{c}\text { Increasing targets } \\
\text { reaching 7.5\% of } \\
\text { electric energy } \\
\text { from renewables }\end{array}$ & $\begin{array}{c}7.5 \% \text { of electric energy } \\
\text { from renewables; 50\% } \\
\text { from new (post-1998) } \\
\text { sources }\end{array}$ & $\begin{array}{c}\text { Equivalent of 25\% of } \\
\text { electric energy from } \\
\text { renewables }\end{array}$ \\
\hline Target Date & 2013 & 2013 & 2025 \\
\hline Mandatory? & Yes & Yes & No \\
\hline $\begin{array}{l}\text { Considers thermal } \\
\text { energy "renewable"? }\end{array}$ & No & Yes & Yes \\
\hline \hline
\end{tabular}

The use of RECs and green power pricing programs to meet the goals of EPAct 2005 are subject to specific guidelines and requirements to avoid double counting RECs. Section 3.3.3 of the 2007 Federal Energy Management Program (FEMP) Renewable Energy RequiremTent Guidance for EPAct 2005 and Executive Order 13423 states the following: 
That portion of renewable energy/RECs that is used by another party (including electric service providers who claim ownership of renewable energy attributes to meet renewable portfolio standards), or transferred or sold by the federal agency to a third party, cannot be counted toward the EPAct 2005 or EO13423 Requirement.

Agencies may not count renewable energy or REC purchases from resources that are included in the utility's normal generation mix. Agencies may not count renewable energy or REC purchases that have been paid for by captive utility ratepayers unless the revenue from the further sale of the renewable energy or RECs is returned to those ratepayers or used for new renewable energy development.

The statements above are some of the many stipulations spelled out in the various guidance documents associated with meeting the renewable energy mandates and goals through the purchase of RECs or green power. Specifically, the important issue of double-counting is addressed, which unfairly allows two groups to count a single renewable resource as unique and their own.

The U.S. Air Force (AF) purchases RECs to meet their renewable energy goals when on-site project renewable energy generation is insufficient to meet goals. Projects are developed on-site when economic, and replacement RECs are typically purchased from the voluntary market at a lower price than the project-generated RECs were sold. Then, additional RECs are purchased from the voluntary market to meet the Department of Defense (DOD) goal.

Currently, purchase of RECs to meet renewable energy goals is against Army policy. Army facilities are instead encouraged to build renewable energy projects or buy renewable energy from off-site projects or utilities, at a cost equal to or less than current costs. However, replacement RECs for on-site projects can still be purchased, similar to the Air Force approach. The purchase of RECs does not count toward other energy efficiency goals. Requirements to reduce energy consumption per square foot of building floor area require reduction in energy use, not replacement of fossil energy with renewable energy.

\subsection{The City of Aspen, Colorado}

To promote energy efficiency and renewable energy, the City of Aspen and Pitkin County, Colorado, enacted the Renewable Energy Mitigation Program (REMP) to the residential and commercial building code in 2000 . The code places a limit on energy consumption in residential and commercial buildings by mandating an "energy budget" for new construction and significant building additions. Property owners who wish to consume energy beyond the energy budget for exterior uses such as pools, spas and heated driveway snow removal must install on-site renewable energy systems or pay a one-time energy mitigation fee. New residential and commercial buildings with exterior energy consumption systems larger than $5,000 \mathrm{ft}^{2}$ or additions to existing buildings that will bring the total area to $5,000 \mathrm{ft}^{2}$ are required to comply with the code along with buildings with outdoor pools, spas or snowmelt systems regardless of the square footage of conditioned floorspace.

Compliance options include installation of an on-site, 2-kW solar PV or equivalent renewable system, a three-panel solar hot water system or a one-time payment into the REMP fund. The fee is $\$ 1$ per $\mathrm{ft}^{2}$ of conditioned floor area, with a minimum fee of $\$ 5,000$ for homes above 5,000 $\mathrm{ft}^{2}$. The mitigation fee for exterior energy consumption is significantly larger than conditioned floorspace; it is calculated as a factor of system square footage and the energy efficiency of the combined systems. For example, a house with $8,220 \mathrm{ft}^{2}$ of conditioned floor area without any exterior energy consumption would be required to pay a compliance fee of $\$ 8,220$. A $3,000 \mathrm{ft}^{2}$ house with $400 \mathrm{ft}^{2}$ of heated driveways, $75 \mathrm{ft}^{2}$ of spa area and 100 $\mathrm{ft}^{2}$ of outdoor pool area would be required to pay $\$ 43,440.86$. 
The primary objective of the REMP program is to decrease energy consumption within the residential sector, not promote expansion of on-site renewable energy systems. Thus, the structure of the program is similar to a luxury tax for high-end home features such as heated swimming pools or heated driveways. Pitkin County has one of the highest per-capita incomes in the United States, and many homeowners have opted to pay the fee rather than install on-site renewable energy systems. This has resulted in high revenues earned through the REMP program. While successful in Pitkin County, it remains uncertain whether similar programs in areas with lower incomes would be effective for on-site renewable adoption.

REMP funds are collected by the Community Office for Resource Efficiency (CORE), which has partnered with local government and utilities to oversee the REMP program. As of 2011, approximately $\$ 10$ million in REMP revenues have been collected by CORE (Ratledge 2011). Funds collected through CORE from Aspen and Pitkin County become funding for community renewable-energy grant programs, extended to utilities and renewable energy developers through CORE.

Cummulative revenues earned through the REMP program total more than $\$ 10$ million as of June 2011; funds from the program have funded more than 75 renewable projects to date (Ratledge 2011). Program funds become grants for small community projects, solar rebate programs and Green Key grants, which fund on-site renewable projects for local government, nonprofit and other approved projects. 


\subsection{Requirement Structure}

Primary requirements for prescriptive on-site renewable energy systems, including PV arrays and alternative compliance options, will be impacted by enforcement issues, building life considerations, and the price of compliance. For the purpose of this report, the following requirement structure assumptions have been made:

- The structure of the requirement wording will be similar to that of the current City of Seattle code or ASHRAE 189.1 requirement, based on either conditioned floor area or roof area. The requirement will be close to $4 \mathrm{~W} / \mathrm{ft}^{2}$ of roof area or $0.5 \mathrm{~W} / \mathrm{ft}^{2}$ of conditioned floor area (Kaufmann 2011).

- The REC compliance will be represented in the same units (either conditioned floor area or roof area).

To determine equivalence for the RECs alternative compliance option, the following assumptions are made:

1. The REC requirement should be designed to be energy-neutral or energy-positive compared to the renewable requirement. This means that the RECs requirement should never be structured for less electricity equivalent energy to be purchased over the life of the building than actual electricity the required PV system would generate.

2. The REC requirement should be structured to be cost-neutral to the PV requirement if possible. This means that the RECs option should not be dramatically less expensive than that of the required PV system. This is a moving target due to the broad range of REC markets, prices, and the fluctuating cost of PV arrays. Cost neutrality is important because while RECs are a good renewable energy investment the purpose of the requirement is to reduce the total environmental impact of a specific building. If off-site renewable energy is purchased rather than installing a PV array or equivalent renewable energy generation system it is unlikely that the building will every install a system retroactively. This represents a lost opportunity for reducing the total building load.

3. The REC requirement should be relatively easy to enforce. This implies that some reasonable amount of documentation may be required but should not be a burden over the life of the building. The structure of the current ASHRAE provisions are considered to be reasonable based on this assessment.

To perform the requirement analysis, several inputs to the described equivalences are summarized in this section. One of the subtle aspects of the alternative compliance path is motivation. It is important that the requirement encourage the construction and development of new renewable energy generation. The actual code requirement developed by Kaufmann et al. (Kaufmann 2011) is structured to encourage this via rooftop solar arrays,, and it is important that the alternative compliance paths not undermine the objective of general renewable energy generation system development.

\subsection{Enforcement}

Enforcement of a RECs compliance path has several potential issues. Documentation of the RECs purchase becomes difficult if a building is constructed and then sold by the developer. The price of the RECs may change over time making it difficult for a developer or code official to determine the best option for a specific building. Additional enforcement issues are discussed by Kaufmann 2011. 
To make the renewable trade-off easy to enforce, two different paths have been chosen by ASHRAE and the City of Seattle.

1. ASHRAE 189.1 allows the builder to purchase RECs either initially or over the first 10 years of the building life.

2. The City of Seattle requires the builder to purchase the RECs completely at the time of construction.

From the enforcement standpoint, the City of Seattle approach is cleaner. The builder has a higher initial cost, but the initial cost of a renewable system would occur at the time of construction as well. This means of requiring the full purchase to occur at the time of construction makes sense. It will also reduce pricing uncertainties for the builder since potential changes in REC prices over time will not be a factor.

In the city of Seattle example the enforcement mechanism is fairly clean; the builder will simply provide proof of the RECs purchase at the time of construction and permitting. The ASHRAE requirement will require additional tracking for the permitting department for ten years after construction. This could be a difficult task for small jurisdictions.

\subsection{Building Life}

Structuring an on-site renewable requirement in a manner that takes into account building lifespan will be an important consideration for both the commercial and residential sectors. The lifespan of PV systems is another factor, but like the HVAC system in a traditional building code it is assumed in this analysis that the system would be replaced by an equivalent PV array at the end of life.

In the commercial sector, the median lifetime of buildings is 70-75 years (DOE 2011a). Building lifespan is an important part of ownership considerations for PV systems and alternative compliance options such as REC purchases. The large up-front costs of a PV array on commercial buildings may not be ideal for a building owner who will sell or lease the building after construction. If the owner will not realize the cost savings associated with the on-site renewable system, they are likely to look for other options for compliance. To mitigate this, a code that considers building lifespan is necessary to ensure the REC purchase is equivalent to renewable energy system installation. ASHRAE Standard 189.1 has attempted to address this issue by requiring a cumulative REC purchase of $70 \mathrm{kWh} / \mathrm{ft}^{2}$ of conditioned floor space, which can be purchased upfront or spread over ten years. This structure would be relatively simple to enforce, although it does not account for the entire building life and therefore is not cost-equivalent to installing a PV system.

Like in the commercial sector, building lifespan considerations are closely related to enforcement issues and the capital costs associated with on-site renewable systems. Traditionally, building lifespans for residential homes are assumed to be 30 years (Taylor 2011), which may be shorter than the actual structure's life but is consistent with the length of most mortgages.

Additionally, tradeoffs in the residential sector may include more options, such as envelope optimization and increased appliance efficiency. Because commercial building codes are more restrictive than residential ones, there is more room for compliance tradeoffs that address a building's lifespan. Future code architects may choose to base the requirement on the PV array lifespan, but it is assumed that replacement of the renewable energy generation system would occur with equivalent products over the life of the building. 


\subsection{PV and REC Capital Costs}

A key factor when defining alternative compliance option requirements for on-site renewable energy systems and RECs is related to the difference in cost for each compliance option. Tables 1 and 2 below illustrate the price differences between installed PV systems and RECs found in the literature. Prices are shown primarily in \$/W for PV systems, but the National Renewable Energy Laboratory (NREL) has given a range of PV costs as $0.20-0.80 \$ / \mathrm{kWh}$ as a national average (Price 2010).

Table 1. Installed PV prices from several literature sources.

\begin{tabular}{|lllll|}
\multicolumn{1}{c}{ Source } & Year & \multicolumn{1}{c}{ Values } & \multicolumn{1}{c|}{ Units } & \multicolumn{1}{c|}{ Citation } \\
\hline Aspen CORE & 2004 & 10.11 & \$/W Colorado & Ratledge, 2011 \\
\hline Aspen CORE & 2007 & 8.46 & \$/W Colorado & Ratledge, 2011 \\
\hline Aspen CORE & 2008 & 7.88 & \$/W Colorado & Ratledge, 2011 \\
\hline Aspen CORE & 2010 & 4.44 & \$/W Colorado & Ratledge, 2011 \\
\hline Go Solar California & 2011 & $8.42($ systems $<10 \mathrm{~kW})$ & \$/W California & Go Solar California, 2011 \\
\hline Go Solar California & 2011 & $7.38($ systems $>10 \mathrm{~kW})$ & \$/W California & Go Solar California, 2011 \\
\hline LBNL & 2009 & $8.4($ systems $\leq 5 \mathrm{~kW})$ & \$/W National Average & Barbose et al, 2010 \\
\hline
\end{tabular}

A separate PNNL study investigated the correct price to use for the cost of installed PV in detail based on current installation estimates. Preliminary results from that study indicate a levelized cost of producing electricity from an array would be approximately $0.25 \$ / \mathrm{kWh}$ given the array size and current installation costs (Russo 2011). This value is consistent with the range proposed in Table 1.

REC prices are also quite variable, as can be seen from Table 2. The average price for the range shown is $\$ 0.019 / \mathrm{kWh}$. This analysis uses this average price from the voluntary markets as an example scenario. In certain locations and within certain REC markets, the results could vary dramatically. The rapid change of RECs prices over time makes it critical to for code language to be updated frequently for a renewable energy generation requirement or the requirement will not remain price-equivalent over time.

Marked increases in the volume of RECs in the voluntary REC markets will inevitably change the market structure. An analysis conducted recently by NREL identified REC markets as a primary driver for an increased demand of renewable energy products in the future. Figure 1 illustrates the forecast of renewable energy demand (which includes RECs, green power purchasing programs, and on-site PV systems) through 2015 in high-growth, low-growth and negative-growth policy impact scenarios. The demand is expected to range from approximately 63 to 157 million MWh annually (NREL 2010).

The future market for RECs, including price implications for future code requirements, is difficult to predict. Future prices of RECs can depend on a variety of factors; for example, prices are likely to rise due to increased demand from RPS or renewable energy goals. On the other hand, saturation of renewable energy in electricity markets can cause marked decreases of REC prices. Code development may further affect market volatility. 
Table 2. 2010 REC Prices for Several Voluntary Markets (DOE 2011b). The average price for this range is $0.019 \$ / \mathrm{kWh}$.

\begin{tabular}{|ll}
\multicolumn{1}{c}{ Source } & \multicolumn{1}{c}{$\begin{array}{c}\text { Price } \\
(\mathbf{k W h})\end{array}$} \\
\hline 3 Phases Renewables & 0.012 \\
\hline 3 Degrees & $0.005-0.015$ \\
\hline Native Energy & 0.008 \\
\hline Native Energy & $0.008-0.01$ \\
\hline Bonneville Environmental Foundation & 0.056 \\
\hline Bonneville Environmental Foundation & 0.024 \\
\hline Bonneville Environmental Foundation & 0.020 \\
\hline Carbon Solutions Group & 0.009 \\
\hline Carbonfund.org & 0.005 \\
\hline Choose Renewables & 0.017 \\
\hline Community Energy & 0.025 \\
\hline GP Renewables \& Trading LLC & 0.002 \\
\hline Good Energy & $0.004-0.015$ \\
\hline Green Mountain Energy & 0.014 \\
\hline Juice Energy & 0.011 \\
\hline Marine Renewable/Marine Interfaith & 0.020 \\
\hline Mass Energy Consumers Alliance & 0.050 \\
\hline Premier Energy Marketing & $0.0095-0.02$ \\
\hline Renewable Choice Energy & 0.005 \\
\hline SKY Energy Inc. & 0.024 \\
\hline Santee Cooper & 0.030 \\
\hline Sky Blue Electric & 0.042 \\
\hline Sterling Planet & 0.0185 \\
\hline TerraPass & 0.005 \\
\hline Village Green Energy & $0.02-0.025$ \\
\hline Waverly Light \& Power & 0.020 \\
\hline WindCurrent & 0.025 \\
\hline WindStreet Energy & 0.012 \\
\hline
\end{tabular}




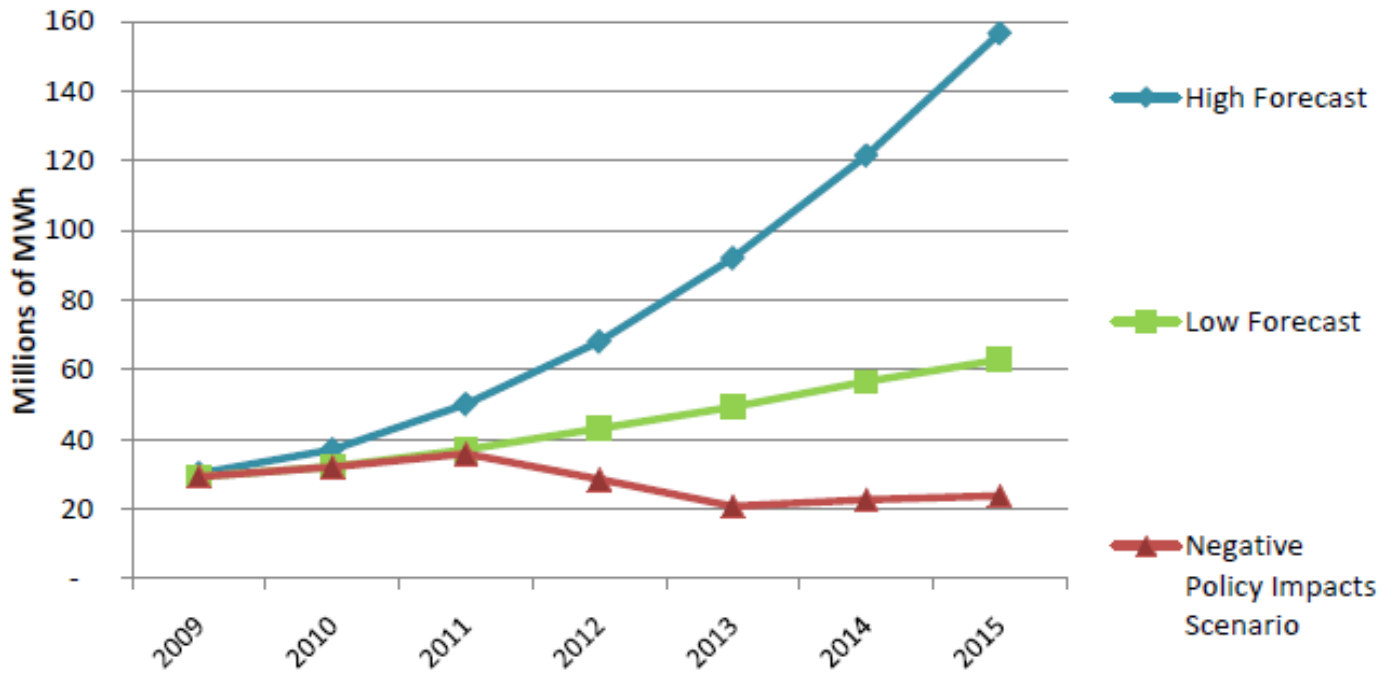

Figure 1. Demand for Voluntary Renewable Energy through 2015 (NREL, 2010). 


\subsection{RECs Alternative Compliance Calculation}

To determine the correct RECs alternative compliance amount for a given region or jurisdiction, the following calculation methodology has been developed to align the objectives of energy neutrality and cost equivalence. The analysis methodology is based on the assumption that most buildings would use photovoltaic systems to comply with a renewable energy generation requirement. The range of possible inputs for the calculation is given in Table 3 .

The purpose of the calculation is to determine the correct trade-off level for RECs (Y) based on the proposed energy code requirement for renewable energy (X). It is important that the REC alternative compliance option be weighted so the code user is encouraged to install PV or another renewable energy technology on-site rather than simply buying RECs because they are the low-cost option. This will help keep compliance with the requirement focused on reducing the energy load of a specific building.

To determine the weighting, $\left(\mathrm{E}_{\mathrm{w}}\right)$, the levelized cost of a PV array $\left(\mathrm{PV}_{\mathrm{p}}\right)$ should be considered along with the price of RECs $\left(\mathrm{R}_{\mathrm{p}}\right)$. The levelized cost of electricity from an array can incorporate externalities including the additional burden of permitting, roof reinforcements, etc. that may deter building owners from installing PV. In essence, $E_{w}$ is a measure of the incentive to pursue offsite RECs as opposed to developing on-site renewable energy systems. When the ratio is 1.0 , there is no incentive to pursue one route over another. When the ratio is greater than 1.0, there is an incentive to pursue off-site RECs; when it is less than 1.0, the opposite is true.

The calculation method below is proposed to provide a simple structure for finding the RECs trade (Y) from the renewable energy requirement $(\mathrm{X})$. This can become complex because the requirement $(\mathrm{X})$ will often be presented in units of $\mathrm{W} / \mathrm{ft}^{2}$ and the RECs requirement should be in $\mathrm{kWh} / \mathrm{ft}^{2}$ or $\mathrm{MWh} / \mathrm{ft}^{2}$. To use the following equation the units of $\mathrm{X}$ and $\mathrm{Y}$ must be the same, however a solar conversion factor has been calculated by Russo et al (Russo 2011) to convert for the average PV installation in the US. For commercial buildings this conversion is $1448 \mathrm{kWh} / \mathrm{kW}$ and for residential buildings this conversion is $1558 \mathrm{kWh} / \mathrm{kW}$.

The price factor $(P f)$ is the ratio of the REC and PV prices as shown in Equation 1. The RECs alternative compliance option level is then calculated from Equation 2.

$$
\begin{gathered}
P f=\frac{R_{p}}{P V_{p}} \\
Y=\frac{X}{P f \cdot E_{w}}
\end{gathered}
$$

The calculation methodology is not appropriate for a code requirement; rather it is proposed as a technique for determining the appropriate code requirements as a possible energy code requirement moves forward in the IECC or ASHRAE consensus process. It could also be used by local jurisdictions as future codes are adopted to adjust the requirement levels at the local level.

It is important to note that the same method could be used to calculate requirements on the basis of conditioned floor area. The units for $\mathrm{X}$ and $\mathrm{Y}$ must be the same but could be altered to reflect an alternative requirement. It is important to note that the price of a REC is not directly comparable to the price of PV as a REC. In the case of RECs, a building owner or developer will still need to purchase traditional energy in addition to the RECs. Code language architects may wish to address this as they determine the best requirement levels. 
Table 3. Description of Calculation Inputs and a Range of Typical Values

\begin{tabular}{|c|c|c|c|c|}
\hline $\begin{array}{l}\text { Variable } \\
\text { Name }\end{array}$ & Description & Units & Typical Values & Sources \\
\hline $\mathbf{X}$ & $\begin{array}{l}\text { Energy code renewable } \\
\text { requirement }\end{array}$ & $\begin{array}{l}\mathrm{W} / \mathrm{ft}^{2} \text { roof area } \\
\text { or } \\
\mathrm{W} / \mathrm{ft}^{2} \\
\text { conditioned floor } \\
\text { area }\end{array}$ & $\begin{array}{l}\leq 4 \\
\text { or } \\
\leq 0.5\end{array}$ & Kaufmann 2011 \\
\hline $\mathbf{Y}$ & $\begin{array}{l}\text { Energy code REC } \\
\text { alternative compliance } \\
\text { option level }\end{array}$ & $\begin{array}{l}\mathrm{W} / \mathrm{ft}^{2} \text { roof area } \\
\text { or } \\
\mathrm{W} / \mathrm{ft}^{2} \\
\text { conditioned floor } \\
\text { area }\end{array}$ & $Y \geq X$ & \\
\hline $\mathbf{R}_{\mathbf{p}}$ & $\begin{array}{l}\text { Cost of REC in local or } \\
\text { national market }\end{array}$ & $\$ / \mathrm{kWh}$ & $\begin{array}{l}0.002-0.06 \\
(0.0019 \text { this } \\
\text { analysis })\end{array}$ & Table 2 \\
\hline $\mathbf{P V} \mathbf{p}_{\mathrm{p}}$ & $\begin{array}{l}\text { Cost of levelized PV in } \\
\text { local market }\end{array}$ & $\$ / \mathrm{kWh}$ & $\begin{array}{l}0.2-0.8 \\
(0.25 \text { this } \\
\text { analysis })\end{array}$ & Table 1 \\
\hline $\mathbf{E}_{\mathbf{w}}$ & $\begin{array}{l}\text { Offsite incentive percent for } \\
\text { RECs }\end{array}$ & & $\leq 1$ & \\
\hline
\end{tabular}

For the purpose of this work has been used to consider future price scenarios for renewable energy and RECs. These scenarios are not intended to represent future price projections, but to illustrate the calculation methodology for weighting RECs over time.

Scenario 1. In this scenario the cost of levelized PV is initially higher than the cost of RECs, but over time the two prices converge. In this case, the requirement for the level of RECs (Y) to make a price-equivalent alternative compliance option is initially higher than the PV requirement (X), but then is reduced as the prices become more comparable. This is illustrated in Figures 2 and 3.

For this scenario, the input value of the renewable requirement was assumed to be the upper end of the recommendation from Kaufman et al. (Kaufmann 2011), $\mathrm{X}=4 \mathrm{~W} / \mathrm{ft}^{2}$ of roof area. The on-site energy incentive was assumed to be $\mathrm{E}_{\mathrm{w}}=50 \%$. 
Scenario 1

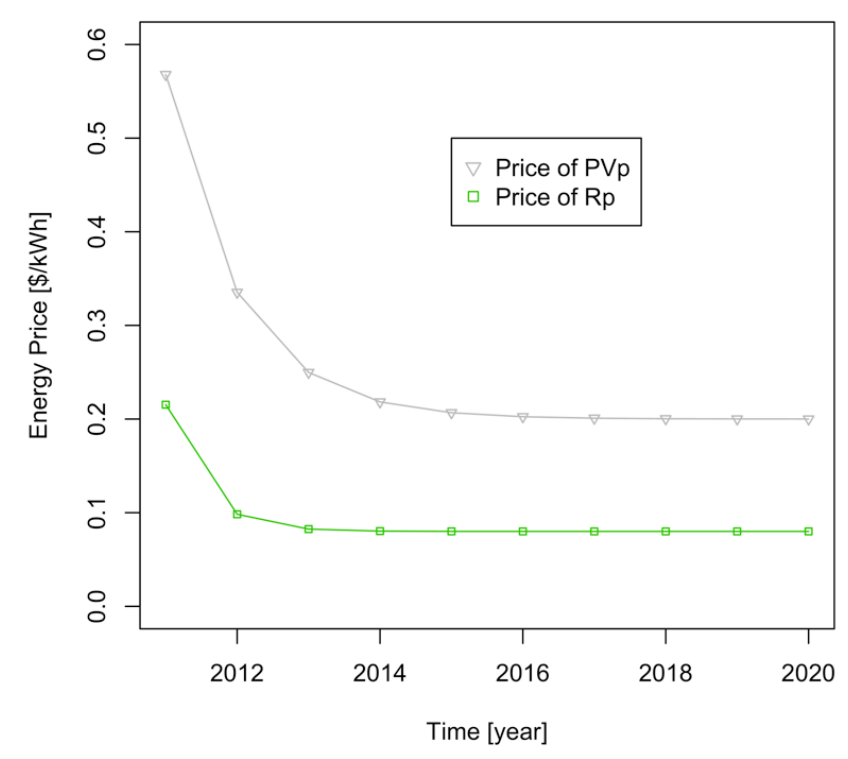

Figure 2. Scenario 1 Price Assumptions. Initially the cost of PV is much more than that of RECs, and then the two prices converge. (This scenario is not intended to represent future price projections).

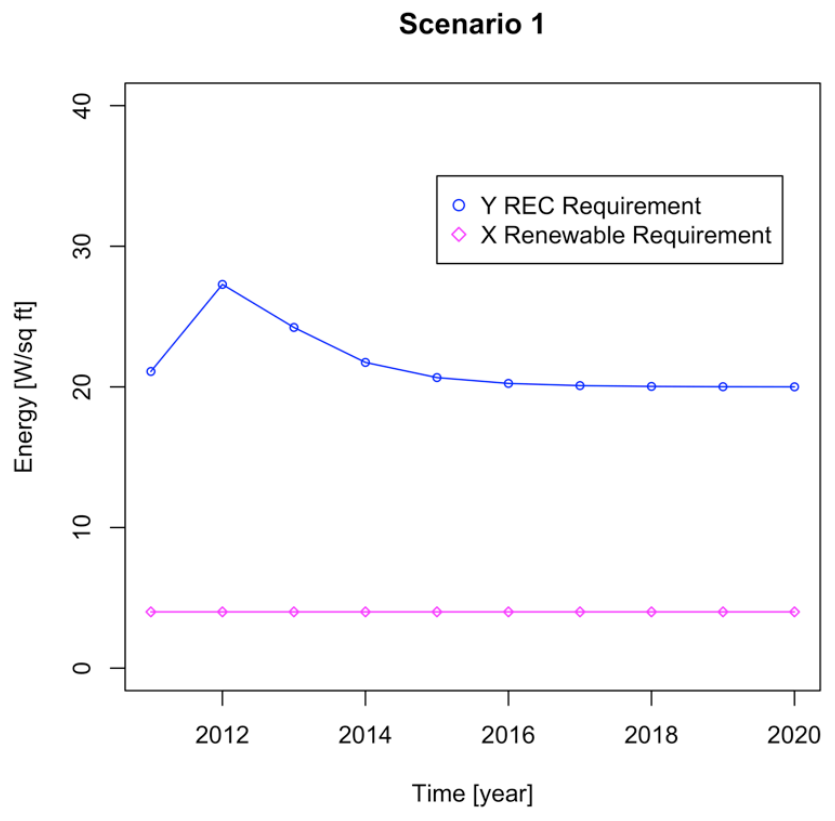

Figure 3. Scenario 1 Energy Requirements. Initially the RECs alternative compliance option requirement would be much more than the PV requirement in terms of energy, and then the two requirements become closer over time. The large buffer between the two requirements is caused by the non-cost weighting factor, $\mathrm{E}_{\mathrm{w}}$, and the price difference between PV and RECs. 
Scenario 2. In this scenario, the cost of levelized PV is initially higher than the cost of RECs, but becomes lower than the price of RECs and then stabilizes. In this case, the requirement for the level of RECs (Y) to make a price-equivalent alternative compliance option is initially higher than the requirement $(\mathrm{X})$ but then is reduced as the prices become more comparable and increases as the prices change again. This is illustrated in Figures 4 and 5.

For this scenario the same assumptions were used, $\mathrm{X}=4 \mathrm{~W} / \mathrm{ft}^{2}$ of roof area and $\mathrm{E}_{\mathrm{w}}=50 \%$.

\section{Scenario 2}

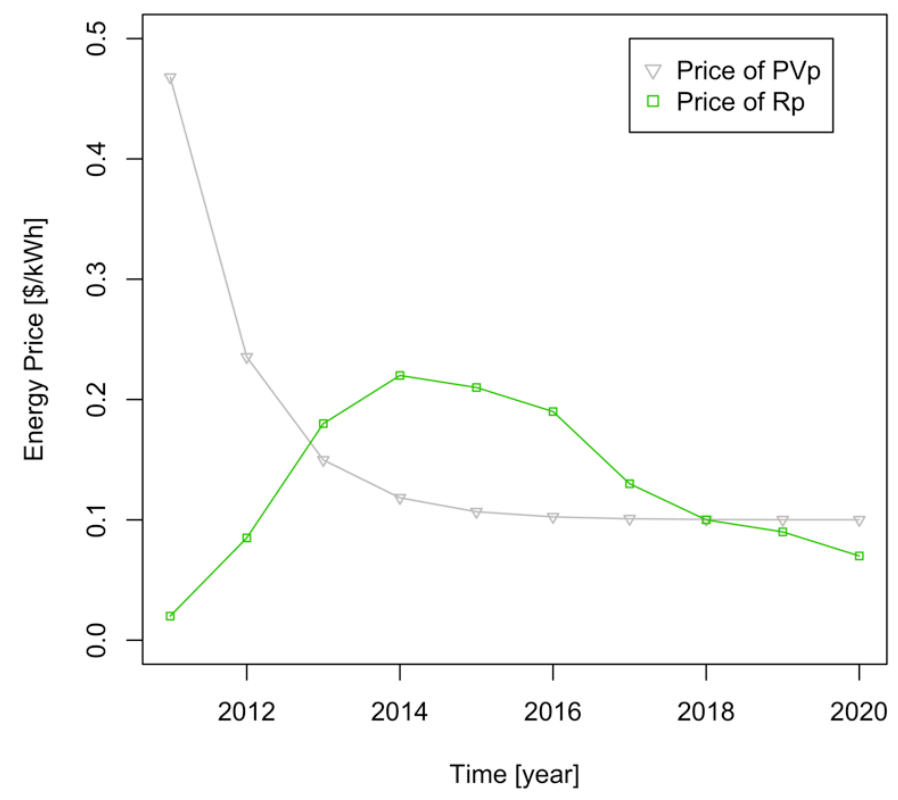

Figure 4. Scenario 2 Price Assumptions. Initially the cost of PV is much more than the price of RECs, and then the two prices converge and then diverge. (This scenario is not intended to represent future price projections).

This scenario touches on another remote possibility that should be considered by the writers of future code language -- that the price of RECs may at some point be more expensive than installing PV. If this occurs the alternative compliance paths should never allow less than an energy equivalent mandate to be in place. Mathematically, $Y \geq X$ for all future requirements. 
Scenario 2

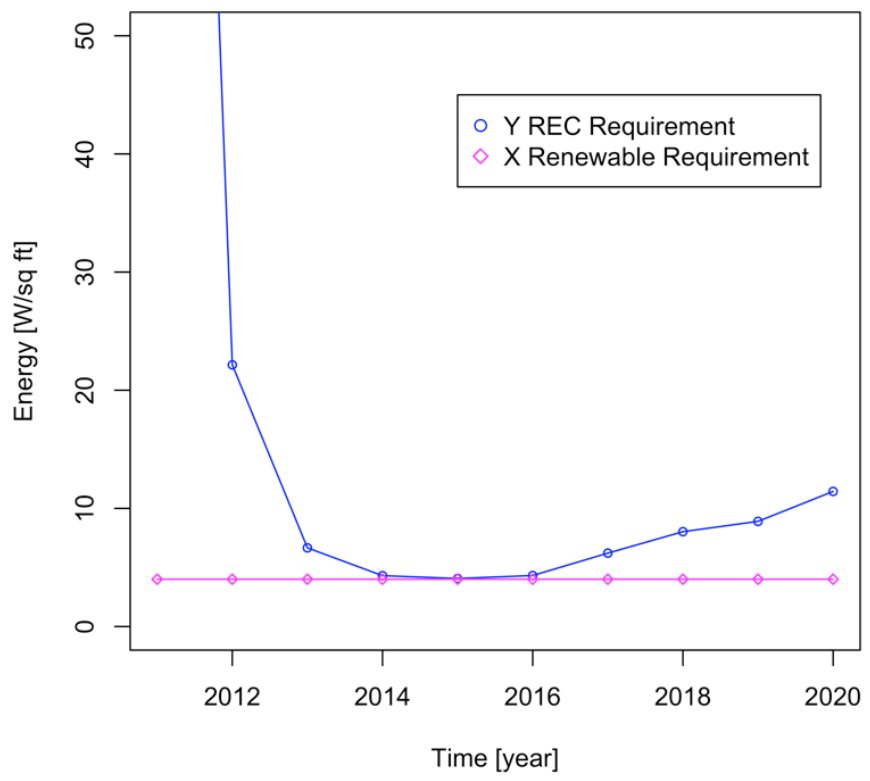

Figure 5. Scenario 2 Energy Requirements. Initially the REC alternative compliance option requirement is much higher than the PV requirement, and then the two requirements become closer over time and diverge again. The buffer between the two requirements at the closest point is caused by the non-cost weighting factor, $\mathrm{E}_{\mathrm{w}}$.

\subsection{RECs Alternative Compliance Calculation Based on Present Prices}

To investigate the current level of alternative compliance options in existing codes, a $10,000 \mathrm{ft}^{2}$, one-story building that is $100 \%$ conditioned is considered as an example. In this example it is assumed that the PV array is installed, maintained, and replaced when needed over a 70 year period.

If this building complies with the ASHRAE 189.1 requirement of $6.0 \mathrm{kBtu} / \mathrm{ft}^{2} /$ year of PV energy, it will be required to install a PV system capable of producing $17,600 \mathrm{kWh} /$ year. If the same building chooses to use a RECs alternative compliance option of $70 \mathrm{kWh} / \mathrm{ft}^{2}$ purchased at the time of permitting, the RECs purchase is only $10,000 \mathrm{kWh} /$ year of renewable energy, close to 57 percent of the energy output of the PV system. This requirement is not energy-equivalent.

The same building constructed in Seattle would be required to install a smaller system, generating only $1,500 \mathrm{kWh} /$ year, according to the City code requirement of $500 \mathrm{Btu} /$ conditioned $\mathrm{ft}^{2} /$ year. The higher REC trade for 2012 (the second year the code is in place) leads to $17,800 \mathrm{kWh} /$ year of renewable energy over the life of the building, 12 times higher than for the PV array. This requirement is energy-positive.

If current estimates for the levelized cost of PV (\$0.25/kWh) (Table 1 and Russo 2011) and the cost of REC average from the table above $(\$ 0.019 / \mathrm{kWh})$ are considered, the price factor is $P f=0.076$. Using the calculation method proposed in Section 3.4 it is possible to solve for the off-site energy incentive for the ASHRAE and Seattle codes. 
The off-site energy incentive $\left(\mathrm{E}_{\mathrm{w}}\right)$ is much greater than 1 for the ASHRAE standard, indicating a strong incentive for the builder to purchase RECs; this is not strictly the case because the ASHRAE standard also requires the proof of poor orientation or shading. Ideally the offsite incentive should be lower than 1, but never greater than 1 because $\mathrm{E}_{\mathrm{w}}=1$ would represent a minimum for price equivalence. The Seattle code is much closer to price equivalence in the second year of the program. These values are summarized in Table 4.

If the calculation method described in Section 3.4 is used for the same example, a different RECs trade would be recommended. Using the Kaufmann et al. suggested maximum PV requirement on the basis of conditioned floor area $\left(0.5 \mathrm{~W} / \mathrm{ft}^{2}\right)$, the renewable energy generation requirement could be as high as 0.72 $\mathrm{kWh} / \mathrm{ft}^{2} /$ year based on an assumed national average capacity factor for power to energy conversion of $1448 \mathrm{kWh} / \mathrm{kW}$ (Russo 2011). Assuming the same pricing scenario and a maximum offsite incentive of $100 \%\left(\mathrm{E}_{\mathrm{w}}=1\right)$, the calculated REC alternative compliance option would be $663 \mathrm{kWh} / \mathrm{ft}^{2}$ for 70 years of building operation.

Using the Kaufmann et al. suggested maximum renewable generation requirement on the basis of roof area $\left(4 \mathrm{~W} / \mathrm{ft}^{2}\right)$, the requirement could be as high as $5.79 \mathrm{kWh} / \mathrm{ft}^{2} /$ year. For the same pricing scenario and a maximum offsite incentive of $100 \%\left(\mathrm{E}_{\mathrm{w}}=1\right)$, the calculated REC alternative compliance option would be $5,334 \mathrm{kWh} / \mathrm{ft}^{2}$ for 70 years of building operation.

Table 4. Existing RECs Alternative compliance option Levels for an Example Building of 10,000 $\mathrm{ft}^{2}$ Assuming a Building Lifespan of 70 Years.

\begin{tabular}{|c|c|c|c|}
\hline Description & ASHRAE 189.1 & City of Seattle & $\begin{array}{l}\text { Recommended } \\
\text { (Kaufmann 2011) }\end{array}$ \\
\hline Renewable Requirement & $1.76 \mathrm{kWh} / \mathrm{ft}^{2} /$ year & $0.15 \mathrm{kWh} / \mathrm{ft}^{2} /$ year & $\begin{array}{l}0.72 \mathrm{kWh} / \mathrm{ft}^{2} / \text { year } \\
\text { (based on } 0.5 \mathrm{~W} / \mathrm{ft}^{2} \text { ) }\end{array}$ \\
\hline $\begin{array}{l}\text { RECs Alternative } \\
\text { compliance option }\end{array}$ & $\begin{array}{l}70 \mathrm{kWh} / \mathrm{ft}^{2} \text { over } 10 \\
\text { years }\end{array}$ & $\begin{array}{l}70 \mathrm{kWh} / \mathrm{ft}^{2} \\
125 \mathrm{kWh} / \mathrm{ft}^{2} \text { in Year Two }\end{array}$ & $663 \mathrm{kWh} / \mathrm{ft}^{2}$ over 70 years \\
\hline $\begin{array}{l}\text { Renewable Requirement } \\
\text { for Sample Building (X) }\end{array}$ & $17,600 \mathrm{kWh} /$ year & $1,500 \mathrm{kWh} /$ year & 7,200 kWh/year \\
\hline $\begin{array}{l}\text { RECs Alternative } \\
\text { compliance option for } \\
\text { Sample Building (Y) }\end{array}$ & $10,000 \mathrm{kWh} /$ year & $17,857 \mathrm{kWh} /$ year & $94,748 \mathrm{kWh} /$ year \\
\hline Offsite Incentive $\left(E_{w}\right)$ & 23.0 & $\begin{array}{l}2.0 \text { year one } \\
1.1 \text { year two }\end{array}$ & 1.0 \\
\hline
\end{tabular}

This comparison indicates that based on current estimates for REC and PV levelized costs, electricity, and building lifespans, the ASHRAE 189.1 alternative compliance option for RECs is low relative to the renewable generation requirement. The City of Seattle trade-off levels are much more reasonable based on current market conditions, but the renewable generation requirement may be lower than the optimum level for the region.

If the building owner purchased the total RECs for the example building (at $\$ 0.019 / \mathrm{kWh}$ ) under the ASHRAE standard the total cost would be $\$ 13,300$ if all the RECs were purchased at the time of 
construction. For the Seattle requirement, the cost would be $\$ 28,880$ in the second year of the program. For a price-equitable trade based on the Kaufmann levels, the total cost would be $\$ 126,015$. These costs are higher than realistic PV system capital costs, and should provide a strong price incentive for builders to install renewable energy systems. 


\subsection{Estimate of Requirement Impacts}

This section outlines potential market impacts of increased PV array installation if a prescriptive renewable generation requirement becomes part of the energy code. This section then expands this analysis to estimate the most dramatic impact to the REC markets.

\subsection{Impact of Commercial Buildings Renewable Requirement}

It is estimated that about 4,701 MW of solar PV arrays would be installed on new commercial buildings in the U.S. in the year 2012 if a building code was adopted which required renewable energy generation of $4 \mathrm{~W} / \mathrm{ft}^{2}$ of roof area to be installed on each new building or major addition based on the assumptions below. This would be a significant increase in installed PV in the U.S. The Energy Information Administration (EIA) estimated that only $640 \mathrm{MW}$ of solar generation capacity (including both solar PV and solar thermal projects) were installed in 2009 (EIA 2011a). BP estimated that 1,642 MW of PV were installed in 2009, and that 2,520 MW were installed in 2010 (BP 2011). These estimates have a large variation, but the highest estimate still shows that commercial building PV installations could nearly triple the amount of PV currently installed in the U.S. in the first year of implementation.

In future years, commercial building construction is expected to continue to increase. Forecasts presented in EIA's Annual Energy Outlook (AEO 2011) were used to estimate potential PV installations on new commercial building rooftops through 2035. Assuming $4 \mathrm{~W} / \mathrm{ft}^{2}$ of roof area are installed on each building, the number of installed MW per year was estimated and is shown in Figure 6.

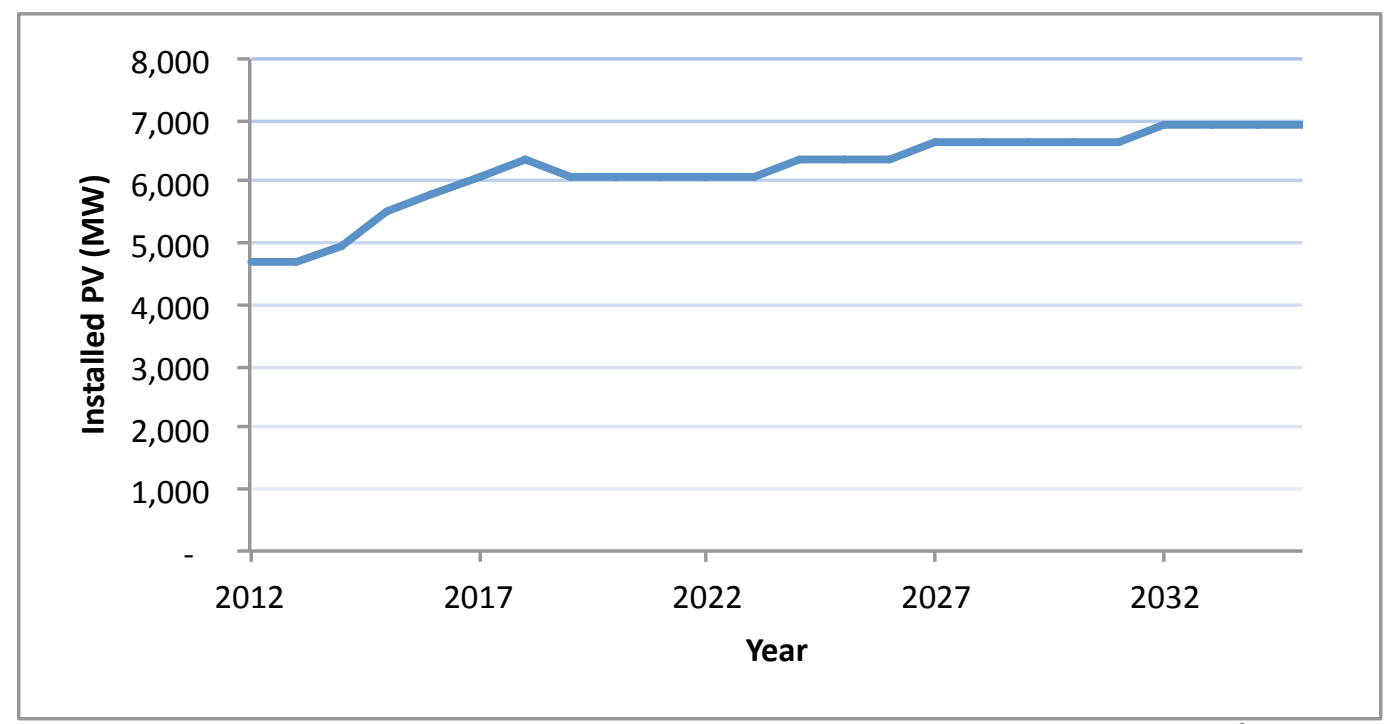

Figure 6: Newly Installed MW by Year on Commercial Buildings, Assuming $4 \mathrm{~W} / \mathrm{ft}^{2}$ of Roof Area

This estimated impact on the PV market is based on a number of assumptions:

1. EIA predicts in AEO 2011 that approximately 1.7 billion square feet of new commercial floor space will be constructed in 2012 (EIA 2011b). This estimate may not fully take into account the impact of the recession and continued economic weakness. AEO's residential estimates have been grossly overestimated in recent years (2009 and 2010 were estimated to have gross additions 
of 1.2 and 1.8 million residences, respectively, but actual residences built totaled 0.8 and 0.7 million, respectively (CR4RE 2011). Further, internal PNNL analysis has shown that residential and commercial construction trends are highly similar by comparison of historic residential permits issued and detailed Commercial Building Energy Consumption Survey (CBECS) data. Therefore, this commercial estimate for 2012 may be high, but it may be representative of a future year.

2. Because the AEO prediction is for total square footage of floor space, the number of floors in each building must be known to calculate the total roof space that may be available for PV panels. Historical building stock characteristics are documented by CBECS (EIA 2008). Unfortunately, this data has not been updated recently and the most recent data available is for 2003; however, it is currently the best available.

3. CBECS also displays building data by year built. It is apparent that commercial buildings in recent years have trended toward one- and two-story structures, with fewer skyscrapers being built. It was assumed for the purposes of this analysis that building height trends in 2012 are similar to those of about 1980 to 2003 . The percentage of buildings within each building size category averaged over those years is charted in Figure 7. These values were used to determine that, on average, 1.45 floors are built per building.

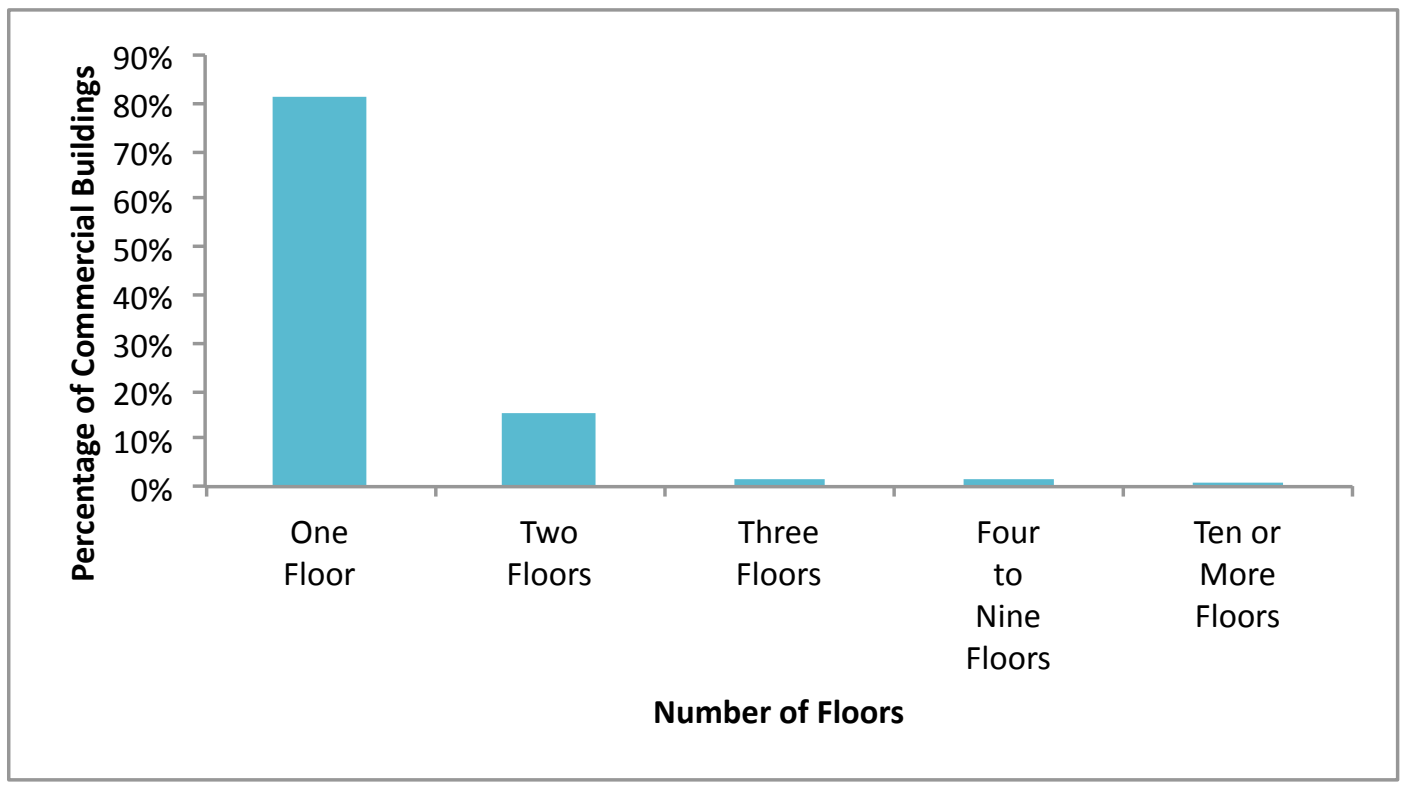

Figure 7: Number of Floors in Commercial Buildings 


\subsection{Impact of Residential Buildings Renewable Requirement}

It is estimated, using the assumptions below, that about 2,959 MW could be installed on new residential construction in the U.S. in the year 2012 if the building code required $4 \mathrm{~W} / \mathrm{ft}^{2}$ of roof area to be installed on each new residential building. This is not as much renewable energy capacity as could be contributed by new commercial buildings, but is significant and still greater than current PV capacity in the U.S. Figure 8 shows the projected PV installations, in MW of capacity, through the year 2035 based on a revised version of EIA's residential construction forecast. Data for the first few years of the EIA forecast were revised by PNNL because they were found to not be representative of recent recession construction. Note that the potential capacity installed each year almost doubles once the housing industry fully recovers from the recession.

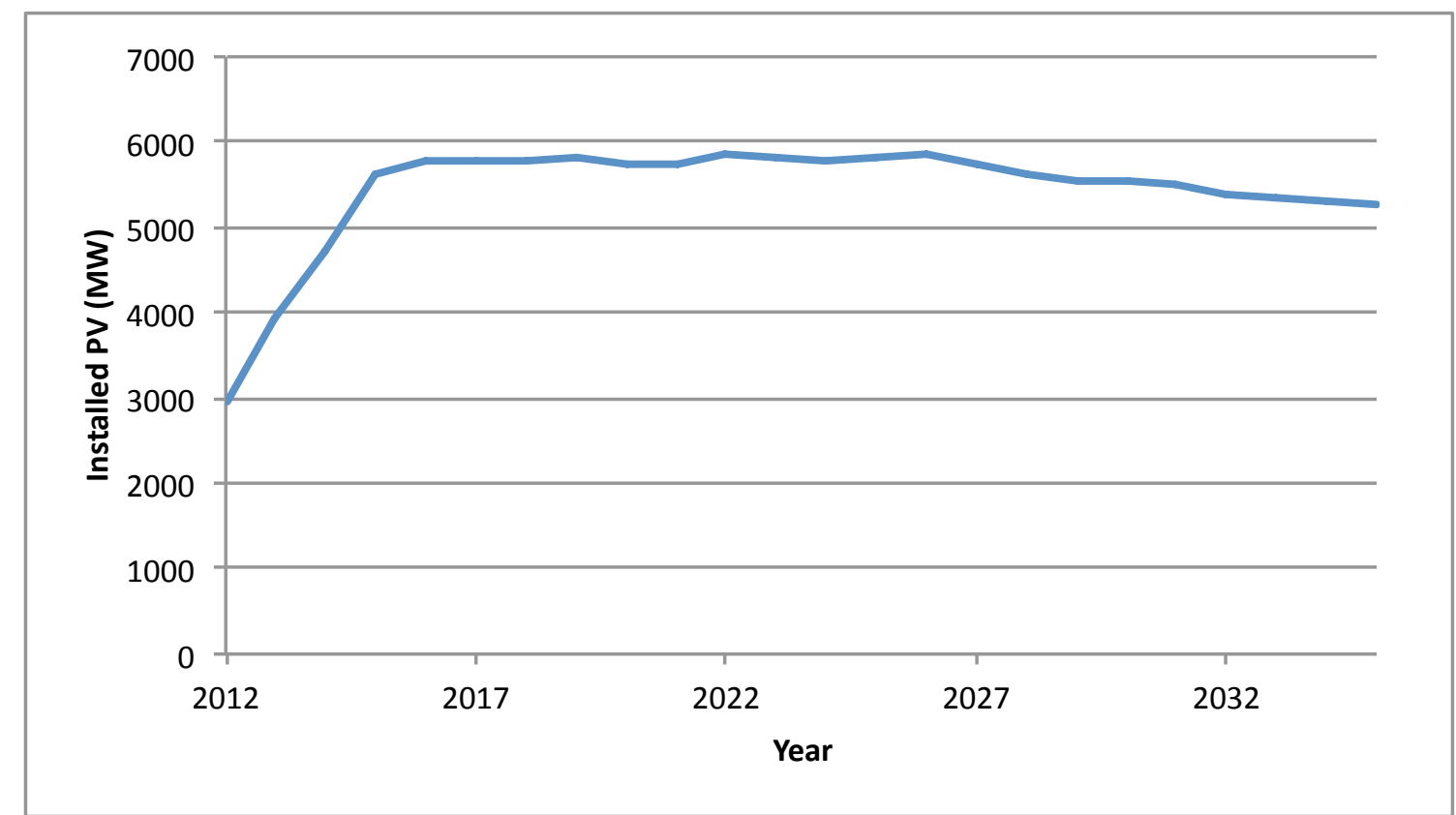

Figure 8: Newly Installed MW by Year on Residential Buildings, Assuming $4 \mathrm{~W} / \mathrm{ft}^{2}$ of Roof Area

This estimated impact on the PV market is based on a number of assumptions:

1. It is estimated that approximately 1.7 million new residences will be constructed in 2012 , based on EIA data (EIA 2011). As stated, this estimate does not fully take into account the impact of the recession and continued economic weakness. Forecasts for years 2012-2014 were adjusted after comparing actual construction data from 2009-2011 (CR4RE 2011) with the 2009-2011 projections based on EIA data. The revised forecast assumes a gradual improvement in the residential construction industry between now and 2015, and assumes 1.0,1.3, and 1.6 million residences, respectively, instead of 1.7, 1.9, and 1.8 for years 2012-2014.

2. Because the EIA prediction is for the total number of residential units, the square footage per unit and the number of floors in each building must be known to calculate the total roof space that may be available for PV panels. U.S. Census data (US Census 2011) contains some information on residential building characteristics, and the Building Energy Codes Program (Taylor 2011) used this data to develop a single-family prototype building that is meant to represent a typical new one- or two-family home or townhouse. This prototype has a floor area of 2,400 square feet and is two stories high, not including basements or attics.

3. U.S. Census data based on the American Housing Survey shows 70 percent of housing units are located in one- or two-story buildings, with a weighted average of about 2.2 stories per residential 
building (US Census 2011). Figure 9 shows the percentage of residential buildings that have one, two, three, or four or more stories. Basements and attics were included in the U.S. Census count of stories, but it is unclear whether they were included in the square-footage calculation; it was assumed they are not. The median unit size is 1,700 square feet. This analysis relies on this more comprehensive data, which accounts for multi-unit residential buildings, as do the EIA predictions of growth in residential construction.

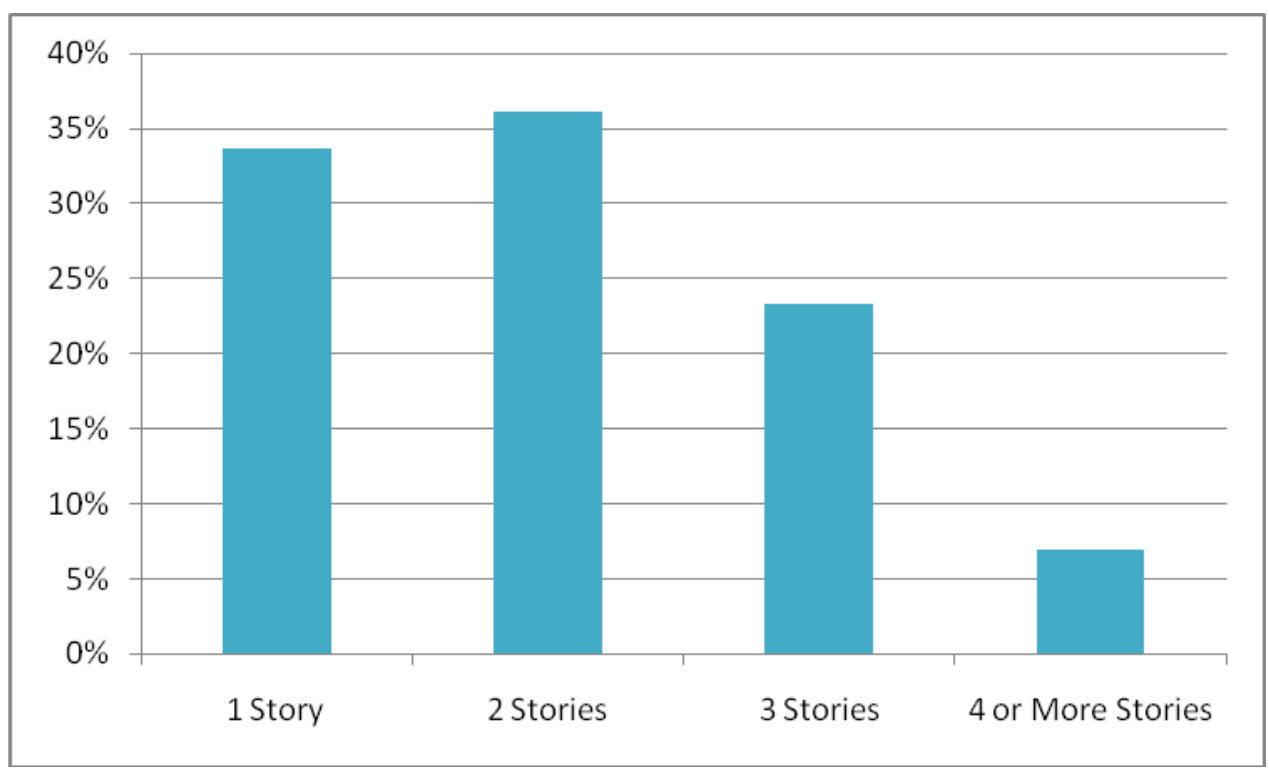

Figure 9: Number of Stories in Residential Buildings. Residential Buildings with more than 4 stories are often considered to be commercial buildings by the model energy codes. 


\subsection{Impact of Commercial Buildings RECs}

As discussed, the RECs alternative compliance option could be structured in a number of ways. The scenarios evaluated are summarized in Table 5 and described in the text below.

Table 5: Summary of worst case impact (100\% compliance via RECs) to the REC markets in 2012 for different code scenarios. For reference, the current REC market is estimated to be 63-157 million MWh

(Bird et al. 2010)

\begin{tabular}{|c|c|c|c|c|}
\hline & \multicolumn{4}{|c|}{$100 \%$ of buildings use RECs compliance } \\
\hline $\begin{array}{l}\text { Renewable Energy Generation } \\
\text { Requirement }\end{array}$ & $\begin{array}{l}4 \mathrm{~W} / \mathrm{ft}^{2} \text { of } \\
\text { roof area }\end{array}$ & $\begin{array}{l}0.5 \mathrm{~W} / \mathrm{ft}^{2} \text { of } \\
\text { conditioned } \\
\text { floor area }\end{array}$ & $\begin{array}{l}4 \mathrm{~W} / \mathrm{ft}^{2} \text { of roof } \\
\text { area }\end{array}$ & $\begin{array}{c}0.5 \mathrm{~W} / \mathrm{ft}^{2} \text { of } \\
\text { conditioned floor } \\
\text { area }\end{array}$ \\
\hline $\begin{array}{l}\text { RECs Alternative Compliance } \\
\text { Option }\end{array}$ & $\begin{array}{c}\text { Energy } \\
\text { Equivalent }\end{array}$ & $\begin{array}{c}\text { Energy } \\
\text { Equivalent }\end{array}$ & $\begin{array}{c}\text { Price } \\
\text { Equivalent } \\
5,334 \mathrm{kWh} / \mathrm{ft}^{2}\end{array}$ & $\begin{array}{c}\text { Price } \\
\text { Equivalent } \\
663 \mathrm{kWh} / \mathrm{ft}^{2}\end{array}$ \\
\hline $\begin{array}{l}2012 \text { Projected REC market } \\
\text { impact for one year of energy } \\
\text { equivalent purchases }\end{array}$ & $\begin{array}{l}6.8 \text { million } \\
\text { RECs }\end{array}$ & 1.0 million RECs & 89 million RECs & 13.6 million RECs \\
\hline $\begin{array}{l}2012 \text { Projected REC market } \\
\text { impact for building life } \\
\text { purchases }\end{array}$ & $\begin{array}{l}476 \text { million } \\
\text { RECs }\end{array}$ & $\begin{array}{l}72.6 \text { million } \\
\text { RECs }\end{array}$ & 6.2 billion RECs & 950 million RECs \\
\hline
\end{tabular}

If the requirement were structured such that the number of RECs purchased equaled the amount of energy that would have been generated in one year by a PV array meeting the Kaufmann et al. proposed requirement of $4 \mathrm{~W} / \mathrm{ft}^{2}$ of roof space, approximately 6.8 million RECs would be purchased in 2012 , assuming all new commercial buildings purchased RECs instead of installing PV. This assumes that only one year of REC purchases will be required. If REC purchases for a 70-year building life were required upfront, 476 million RECs would be purchased in 2012. The one-year RECs requirement would be equivalent to a requirement of $4.7 \mathrm{kWh} / \mathrm{ft}^{2}$ of conditioned space.

Another option for a RECs alternative compliance requirement is to use the energy equivalent of the Kaufmann proposed requirement of $0.5 \mathrm{~W} / \mathrm{ft}^{2}$ of conditioned floor space. In this case, 1.0 million RECs would be purchased in 2012 for one year of REC purchases. This also assumes the conservative bound that all buildings choose RECs for compliance. For upfront REC purchases for the 70-year building life, 72.6 million RECs would be purchased in 2012.

Yet further options would be to use the price-equivalent REC requirements calculated in Table 4. For the $4 \mathrm{~W} / \mathrm{ft}^{2}$ of roof space requirement, $5,334 \mathrm{kWh} / \mathrm{ft}^{2}$ are required for a 70 -year building life. If the purchases were spread over the life of the building, 89 million RECs would be purchased in 2012, again assuming all buildings choose RECs for compliance. If the RECs are all purchased in the first year instead, 6.2 billion RECs would be purchased in 2012. The one-year RECs requirement would be equivalent to a requirement of $62.5 \mathrm{kWh} / \mathrm{ft}^{2}$ of conditioned space.

For the $0.5 \mathrm{~W} / \mathrm{ft}^{2}$ of conditioned floor space, $663 \mathrm{kWh} / \mathrm{ft}^{2}$ are required for a 70 -year building life. If the purchases were spread over the life of the building, 13.6 million RECs would be purchased in 2012, again 
assuming all buildings choose RECs for compliance. If the RECs are all purchased in the first year instead, 950 million RECs would be purchased in 2012.

Using the same assumptions described above about future building stock growth, future REC purchases from new buildings could be as high as those shown in Figure 10, if all new buildings purchased RECs instead of installing PV arrays each year according to a price-equivalent requirement. Note that the chart follows the same curve as in Figure 6, because it is assumed all buildings now choose the RECs alternative compliance option. Actual values will vary depending on cost to install PV, and the cost of RECs.

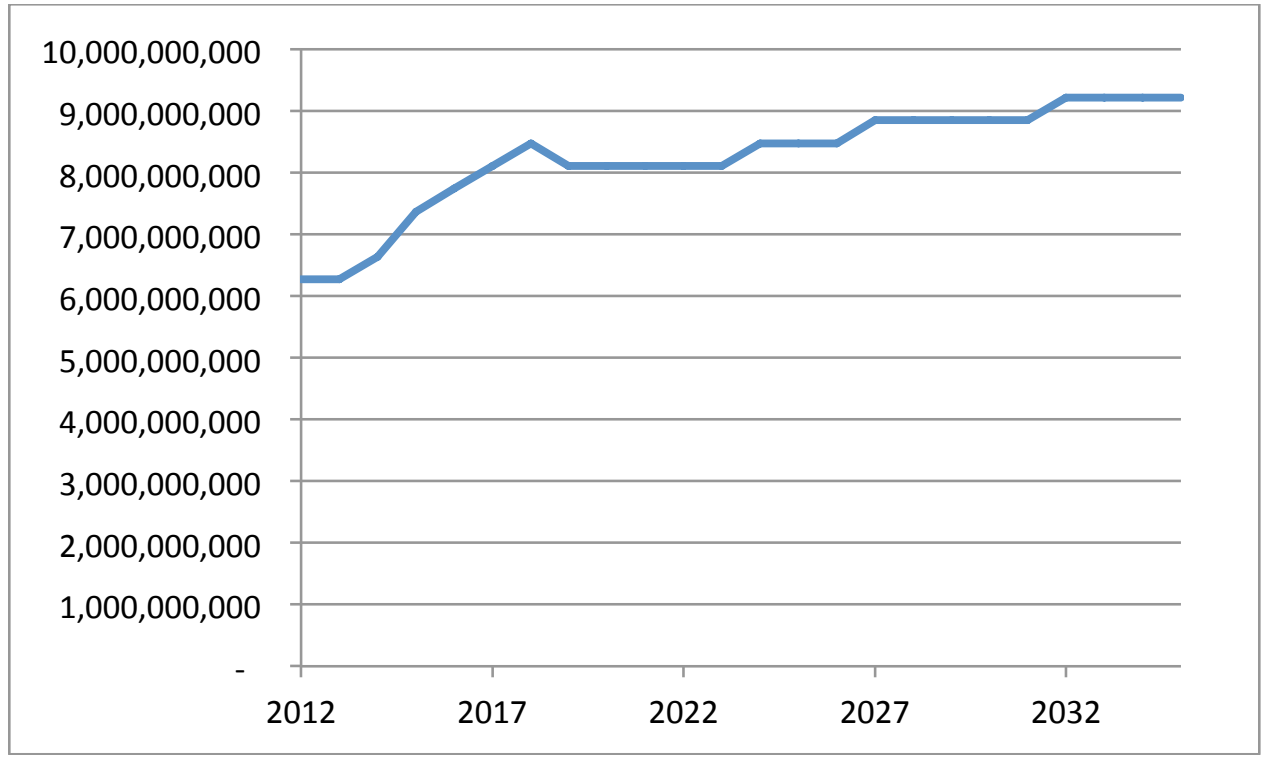

Figure 10: Potential Future REC Purchases for Commercial Buildings Assuming Price Equivalence

EIA's future building stock estimates include total floor space, but this proposed REC requirement is based on conditioned floor space for consistency with the ASHRAE and Seattle requirements. CBECS data (EIA 2008) was used to determine the percentage of conditioned floor space that could be expected based on total floor space predictions. CBECS provides information on heated floor space and cooled floor space, and this data was used to determine total conditioned floor space. The assumptions used in this determination are shown in Table 6.

Table 6: Percent of Building Assumed to be Conditioned Based on Heating and Cooling Characteristics

\begin{tabular}{|lcccc|}
\hline & Not Cooled & $\mathbf{1 - 5 0} \%$ Cooled & $\mathbf{5 1 - 9 9 \%}$ Cooled & $\mathbf{1 0 0} \%$ Cooled \\
\hline Not Heated & 0 & 25 & 75 & 100 \\
\hline $\mathbf{1 - 5 0} \%$ Heated & 25 & 25 & 75 & 100 \\
\hline $\mathbf{5 1 - 9 9 \%}$ Heated & 75 & 75 & 75 & 100 \\
\hline $\mathbf{1 0 0 \%}$ Heated & 100 & 100 & 100 & 100 \\
\hline
\end{tabular}

The amount of unconditioned floor space was subtracted from the total floor space listed in 2003 CBECS data (EIA 2008), resulting in 84 percent of floor space being conditioned. This value was assumed to be similar to that of future building construction.

The amount of electricity that could be generated if a PV array were installed (to determine energy equivalence) was determined using a national average capacity factor of $16.5 \%$. The national average 
capacity factor was calculated on a weighted-average basis, with more weight given to capacity factors in climate zones expected to see more buildings growth. The analysis assumed flat roofs for all commercial buildings.

A 2005 report on REC markets estimated that in 2010 the compliance and voluntary markets would each be about 46 million MWh (Holt and Bird 2005). While this data is out of date and is not an accurate representation of today's market, it provides an order-of-magnitude comparison to the potential impact of an alternative compliance path to a renewable energy requirement in commercial building codes. For instance, the number of states with Renewable Portfolio Standards (RPSs) has more than doubled since the report was released, and the compliance market estimates are based on RPS requirements. Also, as previously stated, voluntary markets in 2015 could include 63-157 million MWh based on more recently analyzed low-growth and high-growth forecasts, respectively (Bird et al. 2010). This also shows a large increase from the 2005 estimates.

Regardless, the impact to the REC markets would be overwhelming even if only $30 \%$ of the buildings comply using RECs (21.8 million to 1.88 billion RECs, depending on the code requirements). This is still at minimum half the estimated 2010 voluntary market, and at maximum 12 times more than the estimated 2015 voluntary market.

This analysis highlights the need to provide proper incentives for buildings to install onsite renewable generation rather than complying with the requirement using RECs. Additional compliance measures like community solar may be needed to offset the possible impact in the REC markets. Using a priceequivalent code requirement may offer additional danger for the REC market impact, but it should reduce the possibility of $100 \%$ compliance via RECs and should be implemented. 



\subsection{Code Language Recommendations}

\subsection{Commercial Recommendation}

Although on-site code requirements can apply to both the commercial and residential sectors, the structure of the requirement, compliance options and enforcement should be handled differently. Building codes in the commercial sector are already more stringent than in the residential sector; many of the efficiency gains in envelope, mechanical and electrical systems have been addressed or will be in the next few code cycles. Therefore, requirements for commercial buildings should be structured as a transition to move away from equipment efficiency increases in the short term. In the Seattle code for example, one compliance option is to increase mechanical system efficiency to 1.10 times higher than the current code (WSL 2011). Although the high efficiency equipment tradeoff is feasible now, maximized equipment efficiencies will be integrated into future codes, rendering this compliance option obsolete.

In general, the language and structure of the renewable requirement should be based on the ASHRAE 189.1 wording, but the basis for the requirement and the requirement levels should be adjusted as shown below. The energy requirement should be structured based on $\mathrm{W} / \mathrm{ft}^{2}$ because panel wattage is provided and vetted for nearly all PV modules sold on the U.S. market. Therefore, most contractors, regardless of sophistication, can typically be assured that they are meeting the requirement if they follow a $\mathrm{W} / \mathrm{ft}^{2}$ code requirement. This format for the requirement will avoid the need for PV array output modeling, which may be especially important in the residential housing construction industry for simplicity. Sample language is proposed in the box below based on the conclusions from Kaufmann et al. (Kaufmann 2011) and the addition of the RECs compliance levels from this report.

On-Site Renewable Energy Systems. Building projects shall contain on-site renewable energy generation systems with an installed power density of no less than $4 \mathrm{~W} / \mathrm{ft}^{2}$ of roof area or $0.5 \mathrm{~W} / \mathrm{ft}^{2}$ of conditioned floor area.

Exception: Buildings that demonstrate compliance with the following are not required to comply with the on-site renewable energy systems:

Purchase of renewable electricity products complying with the Green-e Energy National Standard for Renewable Electricity Products of at least $5,334 \mathrm{kWh} / \mathrm{ft}^{2}$ of roof area or 663 $\mathrm{kWh} / \mathrm{ft}^{2}$ of conditioned floor area at the time of permitting.

The base renewable requirement is derived from the Kaufmann recommendations (Kaufmann 2011), but an equivalent annual energy production is provided in the exception for simplicity in compliance with REC purchases.

The RECs equivalency should be recalculated as the code process moves forward to account for changes in the levelized cost of PV and RECs. Local jurisdictions and states may wish to consider updates to the REC purchase option at the time of adoption for similar reasons. As the levelized cost of PV becomes lower, the high-performance equipment tradeoff should be removed as an exception. 


\subsection{Residential Recommendation}

The Aspen, Colorado example represents only one way to manage a renewable requirement in the residential market. The focus of this work is on the alternative compliance options, rather than the renewable requirement, but several observations about the code requirement structure are presented here. On the residential side, the requirement structure could be similar to the commercial requirement, but the high-performance equipment trade-off should remain in place in the code for longer since residential scale renewable systems will not be as cost-effective as commercial systems. In addition, a compliance option via community renewable generation should be provided which aligns with the success of the existing programs. Sample language is proposed in the box below.

On-Site Renewable Energy Systems. Building projects shall contain on-site renewable energy generation systems with an installed power density of no less than $4 \mathrm{~W} / \mathrm{ft}^{2}$ of roof area.

Exception: Buildings that demonstrate compliance with one of the following are not required to comply with the on-site renewable energy systems:

1. High-performance equipment trade. TBD.

2. Purchase of renewable electricity products complying with the Green-e Energy National Standard for Renewable Electricity Products of at least $5,334 \mathrm{kWh} / \mathrm{ft}^{2}$ of roof area at the time of permitting.

3. Purchase of community renewable energy equivalent to at least $5,334 \mathrm{kWh} / \mathrm{ft}^{2}$ of roof area at the time of permitting.

At this time the specific wording and requirement level have not been determined for a high performance equipment compliance options, but it seems reasonable that only a ground source heat pump and equivalent systems would be viable as an alternative. Seattle's implementation of an efficiency multiplier could also be used.

The wording for the community solar requirement may need to be adjusted based on the structure of the local infrastructure or removed if some jurisdictions are not comfortable with the administrative burden this could create. Aspen actually phrases the requirement in terms of a mitigation fee, which could be calculated by an adopting jurisdiction based on local electricity prices. 


\subsection{Conclusions and Recommended Next Steps}

Several conclusions are possible from this analysis effort:

- Due to the current levelized cost of solar electricity (roughly $\$ 0.25 / \mathrm{kWh}$ ) and the low price of RECs $(\$ 0.02 / \mathrm{kWh})$ a requirement for on-site renewable energy based only on energy equivalence will result in no new construction of building integrated PV arrays. An energy equivalence arrangement will dramatically favor purchase of RECs, and builders will follow the lowest price compliance option.

- To address this issue, the code requirement should be based on price equivalence rather than energy equivalence. An analysis technique for this calculation is proposed to aid future code development work and code adopters.

- The impact on the solar PV and REC markets from a requirement of this type will be dramatic. Additional economic research about market impact should be performed once a draft requirement has been established.

Long-term adoption of on-site renewable systems in building energy codes will require further market, technology and policy analysis. While major issues and preliminary recommendations have been identified both in this paper and in a previous study (Kaufmann et al. 2011), further steps should be taken to ensure proper structure of future code implementation. For example, all the analysis in this document is based on national averages, but in reality solar performance will be heavily dependent on local solar insolation levels as shown in Figure 11, as well as prevailing local electric rates and state policies. Research by Dirks (Dirks 2010) examined related issues in more detail for net zero energy homes. 


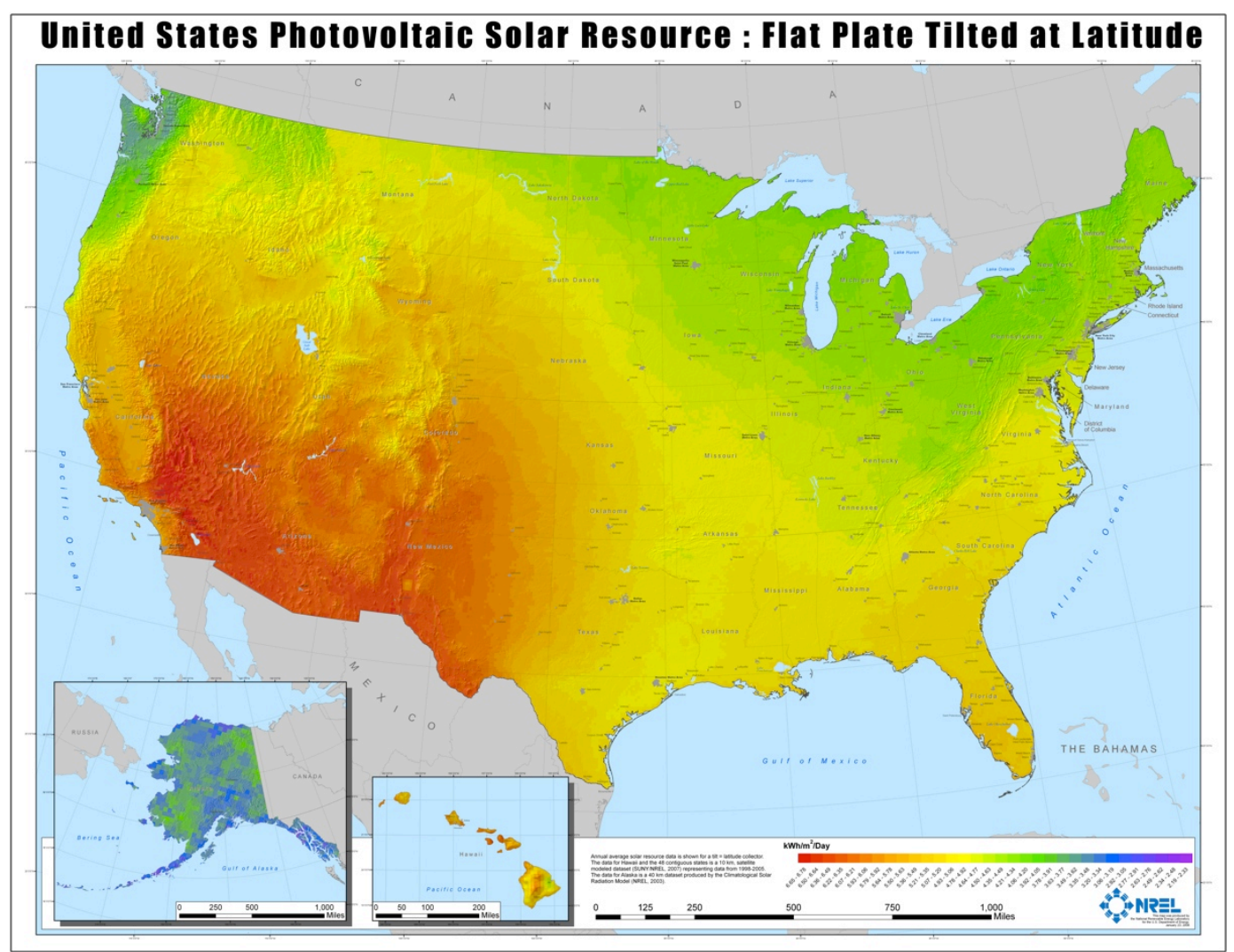

Figure 11. Insolation for Flat-Plate Collectors at Latitude Tilt. In other words, a flat collector (rather than a curved concentrating collector) tilted at each site's latitude (NREL 2011)

Another important factor for code development will be a cost-effectiveness analysis, which is being addressed at a national level in a parallel task. This effort should be combined with a grid and market impact analysis, to determine possible impacts if this requirement is adopted broadly. Although most building integrated PV energy would be utilized by the building, alternative compliance methods such as RECs and community renewable energy programs could result in large changes to the grid infrastructure. A related market impact analysis would attempt to model the potential impact on the compliance and voluntary REC markets. Regional REC market price variations could be considered if additional analysis is performed.

Finally, continued outreach to stakeholders through marketing and planning projects should remain a priority for on-site renewable energy code development. Efforts to involve stakeholders through presentations, meetings, conferences and webinars should continue to be pursued, as should a plan for gathering and organizing feedback from stakeholders. Stakeholder involvement is important for mitigating issues as they arise and incorporating all perspectives into the code development process. 


\subsection{References}

American National Standards Institute, American Society of Heating, Refrigeration and Air-Conditioning Engineers, United States Building Council, Illuminating Engineering Society of North America (ASHRAE). 2010. Standard 189.1: Standard for the Design of High-Performance Green Buildings.

Barbose G, D Darghough, and R Wiser. 2010. Tracking the Sun III: The Installed Cost of Photovoltaics in the U.S. from 1998-2009. Lawrence Berkley National Laboratory- LBNL-4213. Accessed August 23, 2011 at http://www.google.com/url?q=http://eetd.lbl.gov/ea/ems/reports/lbnl4121e.pdf\&sa $=$ U\&ei=XSdUTqiLFc3biAKzr8moCA\&ved=0CBAQFjAA\&usg=AFQjCNEmN2h3oH6ZL 0QQ0wl8uMd8t2qinA

Bird, L., Holt, E., Sumner, J., Kreycik, C. 2010. Voluntary Green Power Market Forecast Through 2015. National Renewable Energy Laboratory, Golden CO: NREL/TP-6A2-48158. Retrieved August 15, 2011 at http://www.nrel.gov/analysis/newsletters/2010 june.html

BP. 2011. Solar Capacity: Solar Power Starts to Show up at Scale. Accessed August 24, 2011 at http://www.bp.com/sectiongenericarticle800.do? categoryId=9037190\&contentId=7068638.

CR4RE_Calculated Risk 4 Real Estate. 2011. On Track for Record Low Housing Completions in 2011. Accessed September 2, 2011 at http://www.calculatedriskblog.com/2011/08/on-track-for-record-lowhousing.html.

Dirks, JA. 2010. An Exploration of Impacts of WideScale Implementation of Net ZeroEnergy Homes on the Western Grid. Pacific Northwest National Laboratory, Richland WA: PNNL-19693

EIA-U.S. Energy Information Administration. 2011. Residential Sector Key Indicators and Consumption, Reference Case. Accessed September 2, 2011, at http://www.eia.gov/oiaf/aeo/tablebrowser/\#release=AEO2011\&subject=0-

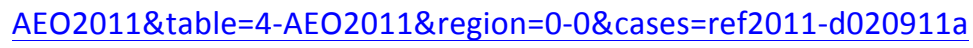

EIA-U.S. Energy Information Administration. 2008. 2003 CBECS Detailed Tables. Accessed September 2, 2011 at http://www.eia.gov/emeu/cbecs/cbecs2003/detailed tables_2003/detailed tables_2003.html.

Farrell, J. 2010. Community Solar Power: Obstacles and Opportunities. The New Rules Project, Minneapolis, MD. Retrieved August 4, 2011 at http://www.newrules.org/sites/newrules.org/files/communitysolarpower.pdf

Go Solar California. 2010. California Solar Statistics. Accessed August 23, 2011 at http://www.californiasolarstatistics.org/ (last updated August 17, 2011).

Green-e Energy. 2011. National Standard Version 2.1. Retrieved 15 2011, June, from http://www.greene.org/getcert_re stan.shtml

Price, S., Margolis, R. et al. 2010. 2008 Solar Technologies Market Report. Prepared for the U.S.

Department of Energy by the National Renewable Energy Laboratory. Golden, CO. Retrieved August 23, 2011 at http://www.nrel.gov/analysis/market_re data_solar.html

Holt E and L Bird. 2005. Emerging Markets for Renewable Energy Certificates: Opportunities and Challenges. NREL/TP-620-37388, National Renewable Energy Laboratory, Golden, CO. Accessed September 2, 2011 at http://www.eere.energy.gov/greenpower/resources/pdfs/37388.pdf. 
International Code Council. 2010. International Green Construction Code. Public Version 2.0.

International Code Council. 2011. 2011 Proposed Changes to the International Green Construction Code. Public Version 2.0.

Kaufman, J.R., Hand, J.R., Halverson, M. 2011. Integrating Renewable Energy Requirements Into Building Energy Codes. Pacific Northwest National Laboratory, Richland WA: PNNL-20442.

NREL. 2011. Insolation for Flat-Plate Collectors at Latitude Tilt Map. Accessed August 22, 2011 at http://www.nrel.gov/gis/images/map_pv_national_hi-res.jpg

Ratledge, Nathan. Executive Director, Community Office for Resource Efficiency (CORE). May 20, 2011. Personal Communication with Chrissi Antonopoulos, Pacific Northwest National Laboratory.

Russo BJ., Weimer, M. Dillon, HE. 2011. Draft report: Renewable Energy Requirements for Future Building Codes: Energy Generation and Economic Analysis, Pacific Northwest National Laboratory, Richland WA

Taylor, Z.T., Lucas, R. 2011. Draft RFI for Economic Assessment of Residential Building Energy Codes. Pacific Northwest National Laboratory, Richland WA

U.S. Census Bureau. 2011. 2011 Statistical Abstract. Construction \& Housing: Housing Units and Characteristics. Accessed August 22, 2011 at

http://www.census.gov/compendia/statab/cats/construction housing/housing units and characteristics.ht $\underline{\mathrm{ml}}$.

U.S. Department of Energy (DOE). Energy Efficiency and Renewable Energy. 2011a. Buildings Energy Databook. Chapter 3: Commercial Sector. Table 3.2.7: Commercial Building Median Lifetimes (Years). Accessed August 24, 2011 at http://buildingsdatabook.eere.energy.gov/TableView.aspx?table=3.2.7.

U.S. Department of Energy (DOE). Energy Efficiency and Renewable Energy. 2011b. Green Power Markets: Renewable Energy Credits (RECs). Retail Prices. Accessed July 20, 2011 at http://apps3.eere.energy.gov/greenpower/markets/certificates.shtml?page=1 (last updated July 22, 2011).

U.S. Energy Information Administration (EIA 2011b). 2011. Annual Energy Outlook 2011. Commercial Sector Key Indicators and Consumption, Reference Case. Accessed August 22, 2011 at http://www.eia.gov/oiaf/aeo/tablebrowser/\#release=AEO2011\&subject=0-AEO2011\&table=5AEO2011\&region $=0-0 \&$ cases $=$ ref2011-d020911a.

U.S. Energy Information Administration (EIA 2011c). 2011. Annual Energy Outlook 2011. Residential Sector Key Indicators and Consumption, Reference Case. Accessed August 22, 2011 at http://www.eia.gov/oiaf/aeo/tablebrowser/\#release=AEO2011\&subject=0-AEO2011\&table=4AEO2011\&region $=0-0 \&$ cases $=$ ref2011-d020911a.

U.S. Energy Information Administration (EIA 2011a). 2011. Electric Power Annual. Electric Power Industry 2009: Year in Review. Accessed August 22, 2011 at http://www.eia.gov/cneaf/electricity/epa/epa sum.html.

U.S. Energy Information Administration (EIA 2011d). Residential Energy Consumption Survey. Accessed August 22, 2011 at http://www.eia.gov/consumption/residential/data/2009/. 
Washington State Leglislature (WSL). 2011. Washington State Administrative Code, Title 51: General Administration. Chapter 51-11: Washington State Energy Code 2009 Edition. Chapter 16: On-Site Renewable Energy Systems. Retrieved June 15, 2011, from http://apps.leg.wa.gov/wac/default.aspx?dispo=true\&cite $=51-11$ 


\section{Appendix A - Additional Code Language}

Proposed language for the IGCC (IGCC 2011).

\section{SECTION 611 \\ BUILDING RENEWABLE ENERGY SYSTEMS}

611.1 Renewable energy systems requirements. Buildings that consume energy shall comply with this section. Each building or surrounding lot or building site where there are multiple buildings on the building site shall be equipped with one or more renewable energy systems in accordance with this section.

Renewable energy systems shall meet the requirements of Section 611.2 for solar photovoltaic systems, Section 611.3 for wind systems, or Section 611.4 for solar water heating systems, and Section 611.5 for performance monitoring and metering of these systems as approved by the code official. These systems shall be commissioned according to the requirements of Section 612.

\section{Exceptions:}

Buildings or building sites where there are multiple buildings on the building site providing at least two percent of the total estimated annual energy use of the building, or collective buildings on the site, with on-site renewable energy using a combination of renewable energy generation systems meeting the requirements of Section 611.2, 611.3, or 611.4.

Where not less than four percent of the total annual building energy consumption from renewable generation takes the form of a ten-year commitment to renewable energy credit ownership, confirmed by the code official.

1. Where the combined application of on-site generated renewable energy and a commitment to renewable energy credit ownership as confirmed by the code official, totals not less than four percent of the total annual building energy consumption from renewable generation.

611.1.1 Building performance-based compliance. Buildings and surrounding property or building sites when there are multiple buildings on the building site, that seek compliance with this code in accordance with Section 602.3.2, performance-based compliance, shall be equipped with one or more renewable energy systems that have the capacity to provide not less than two percent of the total calculated annual energy use of the building, or collective buildings on the site, with on-site renewable energy in accordance with Section 603.

611.1.2 Building prescriptive compliance. Buildings and surrounding property or building sites where there are multiple buildings on the building site, that seek compliance with this code in accordance with Section 602.3.1, Prescriptive compliance, shall be equipped with one or more renewable energy systems that have the capacity to provide not less than two percent of the total estimated annual energy use of the building, or collective buildings on the building site, with on-site renewable energy by calculation demonstrating that on-site renewable energy production has a rating of not less than $1.75 \mathrm{Btu} / \mathrm{hr}$ or not less than 0.50 watts per square foot of conditioned floor area, and using any single or combination of renewable energy generation systems meeting the requirements of Sections 611.2, 611.3, or 611.4. 



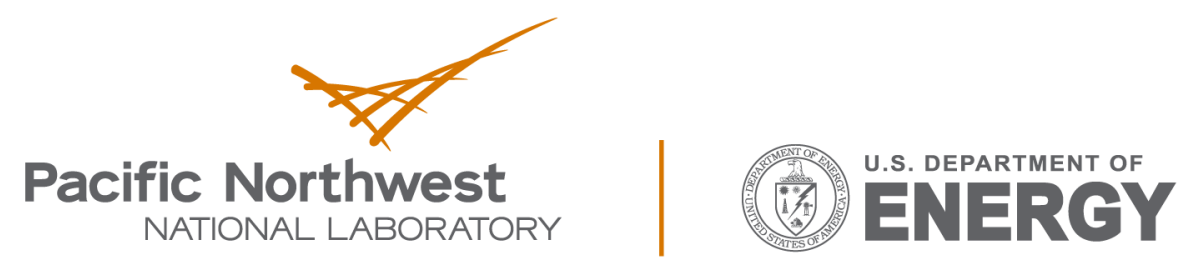

Proudly Operated by Battelle Since 1965

902 Battelle Boulevard

P.O. Box 999

Richland, WA 99352

1-888-375-PNNL (7665)

www.pnnl.gov 